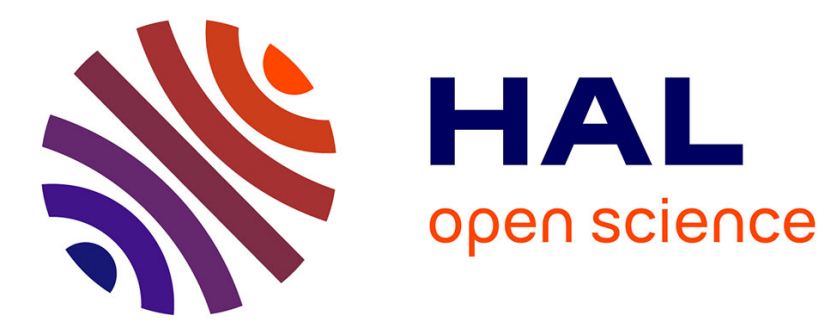

\title{
Medical Provision in the Convents of Poor Clares in Late-eighteenth-century Hungary
}

Katalin Pataki

\section{To cite this version:}

Katalin Pataki. Medical Provision in the Convents of Poor Clares in Late-eighteenth-century Hungary.

Cornova, 2016, 6 (2), pp.33-58. halshs-01534725

\section{HAL Id: halshs-01534725 \\ https://shs.hal.science/halshs-01534725}

Submitted on 8 Jun 2017

HAL is a multi-disciplinary open access archive for the deposit and dissemination of scientific research documents, whether they are published or not. The documents may come from teaching and research institutions in France or abroad, or from public or private research centers.
L'archive ouverte pluridisciplinaire HAL, est destinée au dépôt et à la diffusion de documents scientifiques de niveau recherche, publiés ou non, émanant des établissements d'enseignement et de recherche français ou étrangers, des laboratoires publics ou privés.

\section{(1)(1) $\$(0)$}

Distributed under a Creative Commons Attribution - NonCommercial - ShareAlikel 4.0 


\section{Katalin Pataki \\ Medical Provision in the Convents of Poor Clares in Late- eighteenth-century Hungary*}

abstract: The article sets into focus the everyday practices of caring the sick in the Poor Clares' convents of Bratislava, Trnava, Zagreb, Buda and Pest with a time scope focused on the era of Maria Theresa's and Joseph II's church reforms. It evinces that each convent had an infirmary, in which the ill nuns could be separated from the rest of the community and nursed according to the instructions of a doctor, but the investigation of the rooms and their equipment also reveals significant differences among them. While the infirmary was merely a sickroom with three or four beds in the case of the smaller communities of Zagreb and Pest, the bigger convents' infirmaries - that accommodated nine-twelve patients - consisted of a complex set of interconnected spaces with various functions, including storage rooms, cooking facilities and places for making medicine. The infirmary chapels of Bratislava and Trnava and the liturgical equipment in the bigger, hall-like sickroom in Buda represent the interconnectedness of spiritual and medical care. The study also sheds light on possible correlations between self-supply and services provided by external lay practitioners, as it presents the strategies of the convents to reduce medical expenses, e.g. by producing medicaments, accepting novices with surgical-apothecary knowledge or contracting surgeons and physicians for a fixed annual salary. Finally, the paper points towards further research directions suggesting a more sophisticated analysis of the correlations between the nuns' demand for proper medical care and their agency at the time of the abolition of their order in 1782.

Keywords: medical provision; infirmary; material culture; monastic medicine; monastic spaces; apothecary; domestic pharmacy; medical knowledge; medicaments; surgeon; physician; abolition; Bratislava; Trnava; Zagreb; Buda; Pest; Joseph II; Poor Clares

Glíčová slova: XXX

Kontakt: CEFRES PhD Fellow, Central European University, Department of History

\section{Introduction $^{1}$}

Clara Kuthy, the abbess of the Poor Clares convent of Pest fulfilled probably one of her last duties when she appealed to Emperor Joseph II in July 1782 in order to ensure medical provision for the sick members of her community. She asked for the coverage of the nuns' medical expenses, including the price of medicaments and the remuneration of a surgeon and a physician. ${ }^{2}$ She would not have turned to the ruler with such

* I wrote this article as a $\mathrm{PhD}$ fellow of the Centre français de recherche en sciences sociales - Prague (CEFRES) - USR 3138 CNRS-MAEDI.

1 I transcribe the quoted sources according to the following principles: abbreviations are expanded in full in square brackets [ ], except monetary units. Distinguishing signs above the letters that do not indicate changes in the sound are transcribed without the sign, e.g. ů as u, ÿ as y and š as s. In Latin texts ē is substituted with e (e.g. ex), à (e.g. endings in ablative) with a. The ligatures æ, œ and \&are replaced with ae, oe and et. Different forms of s (long, rounded) appearing in the German texts are not maintained except $\aleph_{\text {. }}$ = is replaced with - if it is used to join words. I keep the original punctuation of the manuscripts, breaks between lines and paragraphs are indicated with /. Sections left out from the quote are marked with three dots, e.g. /.../.

$2 \quad$ "Endes unterzeichnete bittet in Namen deren sam[m]entlichen hier aufgehobenen, und gemeinschaftlich beysam[m]en wohnenden Ex Clarisserinnen um die allerhöchstes Gnad:/ ${ }^{\text {mo }}$ Sowohl de- 
a request if the circumstances had not been exceptional: by the time she made her appeal, the abolition of the Order of Saint Clare had already been in progress by order of the emperor himself.

Joseph II abolished the contemplative religious orders of the hereditary lands in a decree issued on $12^{\text {th }}$ January $1782 .{ }^{3}$ The decision was justified with the lack of their social utility, as the contemplative lifestyle implied a restricted contact with the secular world. Even if these monasteries concentrated valuable resources and knowledge within their walls, their inmates could not actively engage in sharing them with the broader society and they easily became the targets of harsh criticism for their "idleness". ${ }^{4}$

The Poor Clares of Pest were one of the first communities in the country that experienced the difficulties of a dissolution. The goods of the monastery were immediately conscribed and confiscated. The nuns got a five months long grace period during which they could stay in the building and arrange their future lives, but they owned nothing in the convent except the everyday objects in their cells that were regarded as their personal property. Even the victuals of the monastery were closed away, the nuns had

nen jezt Krank liegenden, als auch mitlen zeit noch erkranken Könnenden Schwestern die auß der Apotheken nötige Medicamenten von hohen aerario erfolgen zu lassen, weil solche von dem ausgeworfenen Diaet-geld pr[ägt] 3oxr nicht konten Verschafet werden. / $2^{\text {do }}$ Auch denen Medicis und Chirurgis welche die Kranken dieses aufgehobenen Klosters, wehren den Zeit unseres beisam[m]en Verbleibens bedienen, die bieshero genossene Remuneration ebenfalls allermildest von dem hohen Aerario zu bewilligen. die sich übrigens füer Kais[erlicher] Mayestaet mit alltiefesten Ehrfurcht zu füssen leget, und als eine Unwürdige Unterthannin erstirbet. / Pest den 24ten Julÿ 1782. / Matter Clara Kütyn Abbtiss[in] des aufgehoben Clarisser Klosters in Pest” Magyar Nemzeti Levéltár, Országos Levéltár - Helytarótanácsi Számvevőség - Alapítványi ügyosztály (C 103): Inventarien der in Hungarn aufgelassenen Klöster [Hungarian National Archives - Accountant Office of the Lieutenancy Council - Department of Foundations - Inventories of the abolished monasteries of Hungary] - Poor Clare convents - Pest - Unterthänigste Bittschrift von der Mater Clara Kutty gewesten Abbatissin des aufgehobenen Pester Clarisser Klosters, f. 376r. (Box 31.)

3 The decree issued for the hereditary lands (that had not been valid at the territory of the Hungarian Kingdom) listed the Carthusian and Camaldolese friaries, the hermitages and the nunneries of the Carmelites, Capuchins, Franciscans and Poor Clares. An adapted version of the decree was prepared at the Hungarian Chancellery (Ungarische Hofkanzlei) and its Latin translation was sent to the Lieutenancy Council (Ungarische Hofkanzlei) on $26^{\text {th }}$ January. The German original was published in Gerhard WINNER, Die Klosteraufhebungen in Niederösterreich und Wien, Wien - München 1967, pp. 82-87. For the Latin version see István KATONA, Historia critica regum Hungariae ex fide domesticorum et exterorum scriptorum concinnata a Stephano Katona: Stirpis Austriacae Ab anno Christi MDCCLXXX Ad annum usque MDCCXCII, Buda 1810, pp. 228-242. A copy of the decree is available in Magyar Nemzeti Levéltár, Magyar Országos Levéltár, Helytartótanácsi levéltár, Magyar Királyi Helytartótanács, Departamentum ecclesiasticum cleri saecularis et regularis (C 71), Normalia [Hungarian National Archives - Archives of the Locotenential Council - Department of the Secular and Regular Clergy - C 71 Normalia] 1782. No 27. 1782/1314, ff. 525-531. (771. bundle)

4 About the demand for a more practical Catholic Church, and its connections with the Catholic Reform and Enlightenment see: Ulrich L. LEHNER, Introduction: The Many Faces of Catholic Enlightenment, in: Ulrich L. Lehner - Michael Printy (eds.), A Companion to the Catholic Enlightenment in Europe, Leiden - Boston 2010, pp. 1-61, see pp. 26-29. About the appearance of criticism in German literary works see Hans-Wolf JÄGER, Mönchskritik und Klostersatire in der deutschen Spätaufklärung, in: Harm Klueting - Norbert Hinske - Karl Hengst (eds.), Katholische Aufklärung: Aufklärung im katholischen Deutschland (Studien Zum Achtzehnten Jahrhundert Bd. 15), Hamburg 1993, pp. 192-207. 
to get along with a daily food allowance assigned to them individually. 5 Nevertheless, Clara Kuthy, the aforementioned abbess of the convent of Pest pointed out in her petition that the daily 30 kreutzer ${ }^{6}$ per capita was not sufficient to cover medical expenses. Her petition implied a refusal of the individual management of health issues and she tried to ensure the former accessibility of medical services for the whole community.

Clara Kuthy's attempt to preserve or restore medical care in the convent's daily life in the midst of the abolition procedure leads to the question what kind of medical practices were eliminated with the dissolution of the five Poor Clares' convents of the Hungarian Kingdom located in Bratislava, Trnava, Zagreb, Buda and Pest.7 Was the Poor Clares' demand and solvency for medical services a significant factor in the medical marketplace of their cities? Could the Poor Clares' convents themselves produce medicaments? Were there members in the community with any kind of medical expertise? How uniform was the convents' medical provision and what kind of local specificities can be revealed?

My study seeks answer to these questions with a time scope mainly focused on the two decades preceding the abolition of the Order of Saint Claire. As it has been mentioned, Poor Clare nuns lived in strict enclosure and investigating their practices of nursing, healing and mourning can shed light on a segment of medical care that was available only for a closed group of people and hardly became the subject of such a careful observations and detailed descriptions as before and at the time of the dissolutions. ${ }^{8}$ A closer look at the spatial arrangements and material culture of the convent

$5 \quad$ The procedure and statistics of the monastery dissolutions of Joseph II is analyzed in detail for the Hungarian Kingdom in Márta VELLADICS, Art Historical Aspects of the Abolition of Monastic Orders during Joseph II’s Reign, in: Ferenc A. J. Szabo - Antal Szántay - István György Tóth (eds.), Politics and culture in the age of Joseph II: [ papers presented at the Mátrafüred ' 96 Conference, held at the Europa Institute Budapest on 19-21 September 1996], Budapest 2005, p. 69-88, Márta VELLADICS, A II József korabeli szerzetesrendi abolíció müvészettörténeti vonatkozásai Doktori disszertáció [The Dissolution of Monasteries During the Reign of Joseph II from an Art Histrorical Perspective PhD Dissertation], Budapest 2001, Márta VELLADICS, A II József korabeli szerzetesrendi abolíció statisztikája (1782-1847) [The statistics of secularization in the age Joseph II and between 1782-1847], Századok 133, 1999, pp. 1259-1278.

$6 \quad$ I refer to monetary units with the abbreviations used in the sources. Fl is abbreviated from the latin word florenus and it refers to gulden (German) or forint (Hungarian). One gulden was equal to 6 o kreutzer or krajcár, abbreviated as x or xr. The gulden was one half of a thaler. A new "thaler standard" was introduced between 1753-1755 for the South German territories, the Bohemian and Hungarian lands, and for Upper and Lower Austria, according to which 10 thaler, i.e. 20 gulden equaled to a Cologne mark of silver, and 12 thaler, i.e 24 gulden to the Vienna mark. P. G. M. DICKSON, Finance and government under Maria Theresia, 1740 -1780, Oxford 1987, 1. vol., pp. 34, 369-371.

7 They cover all the dissolved female convents of the Hungarian Kingdom, except the Augustinian canonesses of Eisenstadt.

8 The medical care provided by monasteries for their own inmates has been studied in the medieval context. Guenter B. RISSE, Mending bodies, saving souls: a history of hospitals, New York 1999, pp. 98-106; Jörg SONNTAG, Klosterleben im Spiegel des Zeichenhaften: symbolisches Denken und Handeln hochmittelalterlicher Mönche zwischen Dauer und Wandel, Regel und Gewohnheit (Vita Regularis Abhandlungen Band 35), Berlin 2008, 443-472; J. KERR, Life in the Medieval Cloister, pp. 71-77; Carole RAWCLIFFE, "On the Threshold of Eternity": Care for the Sick in East-Anglian Monasteries, in: Christopher Harper-Bill - Carole Rawcliffe - Richard George Wilson (eds.), East Anglia's History: Studies in Honour of Norman Scarfe, pp. 41-72. About the medical knowledge women could acquire and their activity in eighteenth-cen- 
can also reveal modalities of coping with illness that remained unreflected in other contemporary reports on monastic life and medicine. ${ }^{9}$ Besides exploring the rooms, equipment and personnel the convents dedicated to the care of its sick inmates I also investigate the nunneries' contacts with lay practitioners and the possible correlations between self-supply and external medical services.

\section{Medical care in the rule and constitutions of the Order of Saint Clare}

\section{The Poor Clares' houses came to existence in a broad time span. The first Poor Clares'} convent of the Hungarian Kingdom was founded in Trnava in 1239, the second one came to existence at the end of the thirteenth century. These two convents - unlike the ones in Óbuda, Velena (Oradea), Sárospatak, and Cluj-Napoca - survived the devastations of the Ottoman wars and operated until 1782.10 The convent of Zagreb was founded in 1649, when the local bishop invited nuns from Bratislava as a counteraction to Protestant influence. ${ }^{11}$ The monasteries of Buda and Pest came to existence in 1714 and $1729 .{ }^{12}$ The Poor Clares enjoyed the support of aristocratic families and their

tury convents see Janine Christina MAEGRAITH, Nun apothecaries and the impact of the Secularization in Southwest Germany, Continuity and Change 25, 2010, pp. 313-344. In the Hungarian context, male mendicants appear as surgeons and apothecaries of the countryside, regularly crossing the boundaries between domestic and public services. Márta DECSI - SZILI FERENCNÉ, A gyógyszerészet megjelenése és fejlődése Somogy megyében 1760-1950-ig [The Beginnings and Development of Pharmacology in Somogy county 1760-1950], Budapest, 1988, pp. 36-41. A short description of the infirmary of the Franciscans of Győr: Endre CSATKAI, A györi ferencesek hajdani betegszobájának leltára 1786-ban [Inventory of the Franciscans' Infirmary in Győr in 1786], in: Ákos Palla (ed.), Orvostörténeti Közlemények (Az Országos Orvostörténeti Könyvtár Közleményei 6-7.) Budapest 1957, pp. 275-277.

9 About the potentials of studies on material culture for historical research see Frank TRENTMANN, Materiality in the Future of History: Things, Practices, and Politics, Journal of British Studies 48, 2009, pp. 283-307. For an exeplary study on the material culture of nunneries see: Silvia EVANGELISTI, Monastic Poverty and Material Culture in Early Modern Italian Convents, Historical Journal 47, 2004, pp. 1-20.

10 Nevertheless, both communities had to leave their convents several times during the sixteenth and sevemeteenth centuries. The Poor Clares of Trnava escaped fromtheir convent four times during the seventeenth century $(1619,1644,1663$ and 1683) but they fortunately returned each time. János KARÁCSONYI, Szt Ferencz rendjének története Magyarországon 1711-ig [History of the Order of Saint Francis in Hungary until 1711], 2. vol., Budapest 1924, pp. 470-471.The Poor Clares excaped from Bratislava after the battle of Mohács (1526) and their nunnery was turned into a hospital. The nuns escaping from Óbuda in 1541 reclaimed the building for themselves. The nuns had to escape again in consequence of the Bocskai uprising (1605) and then because of the devastations of the troops of Gabriel Bethlen in 1619 and 1623. Katalin SZENDE - Judit MAJOROSSY, Hospitals in Medieval and Early Modern Hungary, in: Martin Scheutz (ed.), Europäisches Spitalwesen: Institutionelle Fürsorge in Mittelalter und früher Neuzeit $=$ Hospitals and institutional care in medieval and early modern Europe (Mitteilungen des Instituts für Österreichische Geschichtsforschung 51) Wien 2008, pp. 409-454, see p. 450; J. KARÁCSONYI, Szt Ferencz rendjének története, pp. 515-517, 521.

11 Bert ROEST, Order and disorder: the Poor Clares between foundation and reform (The Medieval Franciscans 8), Leiden 2013, pp. 353. J. KARÁCSONYI, Szt Ferencz rendjének története, p. 533.

12 Katalin SCHWARCZ, "Mert ihon jönn Aßonyotok és kezében új szoknyák". Források a klarissza rend magyarországi történetéből [Sources from the History of the Poor Clares of Hungary] (METEM Könyvek 39), Budapest 2002, p. 22. 
members - especially in the convents of Bratislava and Trnava - were often the female descendants of the same families who offered their dowry for the convent before they joined the order. ${ }^{13}$

The Poor Clares of Hungary followed the observance of Pope Urban IV (1261-1264), i.e. a modified version of Saint Clare's rule that allowed the convents to own communal property. It also contains a passage that calls attention to the duty of nursing the sick inmates of the convent and providing them all the necessary services that can facilitate their recovery. It suggests that ill nuns should receive a bed preferably in a room where they can be separated from the rest of the community in order to avoid disturbances in the daily routine of the healthy nuns. ${ }^{14}$

In the first decades of the seventeenth century, the still operating convents of Trnava and Bratislava adopted reforms that enforced monastic discipline and stricter enclosure. ${ }^{15}$ The provincials of the Franciscan Province of the Virgin Mary - to which the nunneries of Bratislava and Trnava also belonged - issued constitutions for the Poor Clares that completed their medieval rule with further, more elaborated instructions. ${ }^{16}$ The constitutions reinforced the principle of taking care of the sick and supplying them with all the means that were necessary for their healing. ${ }^{17}$ Simultaneously, the enclosure of the nuns also manifested itself in more precise regulations regarding the doctor's visit of the patients. Physicians and surgeons were allowed to enter the convent only under the supervision of two or three reliable nuns who guided them in the building and prevented any contact between them and the rest of the community if it was not related to the purpose of their visit. ${ }^{18}$ Even nuns were prohibited to stay in

13 Ingrid KUŠNIRÁKOVÁ, Kláštory klarisiek $v$ Uhorsku - alternatíva spoločenského uplatnenia šlachtických žien $v$ ranom novoveku [The Cloisters of the Poor Clares in Hungary - An Alternative for Self-realization of Noble Women in Early Modern Times], Theatrum historiae 7, 2010, pp. 127-145; Ildikó HORN, Csáky Anna Franciska és a pozsonyi klarisszák, Aetas 1992, pp. 28-43.

$14 \quad$ K. SCHWARCZ, Mert ihon jönn Aßonyotok és kezében új szoknyák, p. 70.

15 According to Eugen Kósa (1717-1783), the Franciscan historiographer of the Marian Province, the convent of Bratislava was reformed in 1607 with the help of three nuns from the Viennese convent, while the Poor Clares of Nagyszombat reformed themselves in 1621 in Zagreb during their escape from Gabriel Bethlen's troops. K. SCHWARCZ, Mert ihon jönn Aßonyotok és kezében új szoknyák, pp. 188., 198-199.

16 Collections of different kind of regulations applying to the Poor Clares were compiled together and translated into Hungarian in the first decades of the seventeenth century. The most complete copy dated from 1635 was made for the nuns of Trnava. It contains the rule of the Poor Clares (confirmed by Urban IV in 1263), modifications of the rule issued by the Holy See, the constitutions issued in the early seventeenth century by the Franciscan provincial János Rudinay with the authorization of the Minister General Franciscus Susa de Toledo and finally copies of papal bulls that affected the Order of Saint Clare. The entire text is published in K. SCHWARCZ, Mert ihon jönn Aßonyotok és kezében új szoknyák, pp. 61-123.

${ }_{17} \quad$ K. SCHWARCZ, Mert ihon jönn Aßonyotok és kezében új szoknyák, p. 93.

18 According to the bull of Pope Alexander VI (1492-1503) issued for Poor Clares three or at least two nuns should escort the doctor to the patient. Physicians or surgeons were not allowed to enter the convent without any meaningful purpose: minor issues, such as a mild cold or merely the wish for consultation could not justify their visit. K. SCHWARCZ, Mert ihon jönn Aßonyotok és kezében új szoknyák, p. 74, 110. 
the infirmary if they had no particular reason to be there and nobody was allowed to disturb the sick with news and chatting. ${ }^{19}$

An eighteenth-century Hungarian manuscript that must have been used as an ordinal book ${ }^{2 \circ}$ in the convents of Buda and Pest contains regulations for the practice of prophylactic venesections to which it refers to as "aestival remedy" (nyári orvoslás). According to the ordinal, the abbess could give permission to phlebotomy from the Holy Week. ${ }^{21}$ The nuns received exemptions from their duties depending on their age and physical condition: the elderly members could stay in the infirmary for two weeks, while the otherwise healthy, younger nuns had to leave the sickroom in three days, although they remained exempt from the more demanding tasks for a week, their presence was required only in the refectory and during common work. The young, but ill nuns could stay in the infirmary for a week, or even longer if their condition made it necessary. The same passage continues with reminding the abbess of her duty to visit the bedridden, seriously ill nuns in the infirmary every day and to support their recovery with every possible means. It was also her responsibility to take the lead in the course of actions if a member of the community was dying. She had to ensure that the moribund person could confess her sins and receive the Extreme Unction. She was also expected to appoint a nun who stayed with the sick and read out loud consoling devotional texts. ${ }^{22}$ Another chapter of the ordinal book describes in detail how the community had to support a dying sister with prayers and singing and what kind of rituals had to be performed during the preparation of the corpse for the funeral. ${ }^{23}$

\section{Medicine in practice - visitations, investigations, dissolutions}

The aforementioned instructions inform about a set of principles and behavioural patterns related to the management of illness in the Poor Clares' convents that also had to be put into practice. Visitations carried out by Franciscan superiors record mainly focused on disciplinary affairs and rarely took mention of anything related to the care of the sick, although the records occasionally repeated the aforementioned duties of the caretakers and warned about the regulations of letting in secular healers into the convent. $^{24}$

19 K. SCHWARCZ, Mert ihon jönn Aßonyotok és kezében új szoknyák, p. 98.

2o It is also a compilation that gives advice regarding the relationship between the community and its superiors, lists the everyday duties of the abbess and her responsibilities in managing the affairs of the convent, enumertes rituals that constitute the daily and annual order of life in the convents and describes the most important feasts of the convent. Its text is published in K. SCHWARCZ, Mert ihon jönn Aßonyotok és kezében új szoknyák, pp. 125-183.

${ }^{21}$ The timing correlated with practical considerations, since convalescents usually needed a warmer environment. Although the sickrooms were equipped with proper heating, the convent sill had to calculate with its resources sparingly. If the venesection took place not as an unavoidable necessity of a treatment, but as a planned, preventive action that could involve a larger number of the nuns, the warmer summer months were the suitable time for that.

22 K. SCHWARCZ, Mert ihon jönn Aßonyotok és kezében új szoknyák, p. 146.

${ }_{33}$ K. SCHWARCZ, Mert ihon jönn Aßonyotok és kezében új szoknyák, pp. 153-154.

24 ŠAB MPF Lad. 29. Fasc. 4 (Box 23). 
State authorities started to supervise the life of the regular clergy more and more intensely from the middle of the 176o's in consequence of the church reforms of Maria Theresa and Joseph II. With the help of a growing administrative apparatus dedicated to church affairs, extensive inquiries were made about the financial status and personnel of the monasteries of the Habsburg lands and the records produced in response to them can be informative regarding medical practices, too. ${ }^{25}$

Maria Theresa ordered the investigation of three Poor Clares' convents in $176 \mathrm{~g}$ including Bratislava, Trnava and Buda. She commissioned Franciscus Berchtold councillor of the Lieutenancy Council (Ungarische Statthalterei) ${ }^{26}$ and bishop of Novi Vinodolski to report about the convents of Bratislava and Buda, while Johannes Galgóczy, the provost (praepositus maior) of the Chapter of Esztergom was in charge of Trnava. ${ }^{27}$ Both of them sent out questionnaires to the convents that inquired into different aspects of their operation and requested answers for their reports in a written form. They prepared their questionnaires in Hungarian, but in slightly different formats. Berchtold's questions were structured into twenty-four paragraphs among which one inquired into the usual procedures in case of illness: it had to be reported whether there was infirmary and personnel in the convent dedicated to the care of the sick and if the patients received medicaments and food according to the prescriptions of a doctor. ${ }^{28}$ Galgóczy's questionnaire was somewhat shorter and illness was discussed among other forms of everyday supply, such as food and clothing. Consequently, it triggered less elaborated answers in terms of medical provision. ${ }^{29}$ Berchtold and Galgóczy also collected data about everyday expenditures including medical expenses and requested information

25 P. G. M. DICKSON, Joseph II's Reshaping of the Austrian Church, Historical Journal 36, 1993, pp. 93-94; Derek Edward Dawson BEALES, Joseph II and the Monasteries of Austria and Hungary, in: Nigel Aston (ed.), Religious Change in Europe 1650-1914: Essays for John McManners, Oxford 1997, pp. 161-184.

26 The name of the Lieutenancy Council is also translated into English as Locotenential Council. It was called Consilium regium locumtenentiale Hungaricum in Latin or Ungarische Statthalterei in German. Its Hungarian name is Magyar Királyi Helytartótanács

${ }_{27}$ The Chapter of Esztergom operated in Trnava at this time that could make the investigation easier. Jakab RUPP, Magyarország helyrajzi története, fö tekintettel az egyházi intézetekre, vagyis nevezetesb városok, helységek, s azokban létezett egyházi intézetek, püspökmegyék szerint rendezve (Historical Topography of the Church Institutions of Hungary], 1. vol., Pest 1870, p. 96.

28 "Beteghes Apáczákra minden Szükséges Gondviselis Vagyon, mihent valaki Beteghsége iránt magát az elő Járonál jelenti, azontol az arra Rendelt betegh-Szobában Helyheztetik, ottan mint fekvésére , Ugy minden egyéb Szükségére alkalmatos hely vagyon, és minden Szolgálattyok meg Vagyon, mert Vannak mindenkor Rendelve Chorusi Apáczak is kik Betegh-Mesternéknek Neveztetnek, ezeknek Hivatallyok, hogy éyel-Nappal, Reájok Vigyázanak, hogy a Doctor Praescriptiojával éllyennek, hogy a Betegeknek Rendelt Gyöngébb ételek meg legyen, egy Szóval hogy őket Jgaz Szerzetes Attyafiui módon mindenben Segítségh, a Doctornak, Borbélynak füzetéssek lévén, Valamikor Szükségh, a Beteghez bé Hivatattnak, és ha Súlyos az Nyavalya Napjában töbször is, a mi módunk és Constitutjóink Szerint bé eresztettnek, ha penig agyban sinlödnek, Vagyon kápolnánk Ugy alkalmaztatva, hogy hogy az Betegh Szobábul, és ágybul is Láthattyak, és Halhattyák, a Sz[ent] Misét. Műdőn penigh Gyógyulni kezdenek Vagyon Más Szoba is a hol mint adig maradnak, még has Doctor jtéleti Szerint Eléghségesseknek tartattnak, kalastrombélj foghlalatosságiknak Véghben Vételére." Magyar Nemzeti Levéltár, Országos Levéltár - Magyar Királyi Helytartótanács - Alapítványügyi iratok (C 39) [Hungarian National Archives - Archives of the Lieutenancy Council - Foundations, abbreviated as MNL OL C 39] Ladula D, Fasciculus 40. 
about the inmates of the convent that can reveal further details about the personnel of the infirmaries.

The abolition of the Order of Saint Clare in 1782 was the moment when secular observers reported about the spaces, equipment, personnel and expenses related to medical provision extensively. The dissolutions were carried out by commissioners delegated by the Lieutenancy Council (Ungarische Statthalterei) and the Hungarian Chamber (Ungarische Kammer) and they were obliged to create a detailed report about the movable and immovable properties of the convents. including an inventory of assets and liabilities. ${ }^{30}$ The asset inventory had to contain a detailed list of the equipment and furnishing that can be especially informative in respect of the spaces dedicated to the domestic care of the sick. Contacts with lay practitioners can be explored with the help of the inventory of liabilities that listed the obligations of the monastery, including the salary of physicians and surgeons and the invoices of pharmacists. ${ }^{31}$

\section{Bratislava}

A functioning infirmary can be evidenced in the convents of Bratislava from 1650 with the help of the protocols reporting about the appointment of the nuns (tabulae) for different offices that include also the names of infirmarers (betegmesternék, betegház mesterei). ${ }^{32}$ Usually $4-5$ persons were appointed for this office whose expertise in nursing and healing could be very different. Apparently, the appointment did not require any prerequisite skills as the personnel of the infirmary changed very often. Nevertheless, the personnel of the infirmary still had a sophisticated inner hierarchy, as it can be revealed from the correspondence of the nun, Anna Franciska Csáky referring to Soror Sophia as the "first infirmarer" (elsö betegmester) and taking mention of three further infirmarers and 2 nurses. ${ }^{33}$ Sophia Derflengerin is listed in the protocols of 1650 and 1659 literally at the first place among the infirmarers. In 1667 - the next protocol is preserved from this year - Sophia Delfengerin is listed among the German secretaries (Nemet Secretariak) and a note is inserted after the name of the infirmarers that suggests them to ask for the advice of Soror Sophia in the management of medical affairs, who should be ready to help them, especially at the presence of a doctor. ${ }^{34}$ Soror Sophia must have been an important figure in the infirmary not only because of her medical expertise, but because of her language skills: most of the inhabitants of the convent

зо M. VELLADICS, Art Historical Aspects, p. 81.

$3^{1}$ The most detailed description of the regulations that determined the main elements of the inventory can be found in Márta VELLADICS, A szerzetes rendek felszámolása II József korában [Dissolution of Religious Orders during the Reign of Joseph II], Egyháztörténeti Szemle 2001. http://www.uni-miskolc.hu/ egyhtort/cikkek/velladics.htm (accessed: 04.10.2016).

32 ŠAB MPF Lad. 29, Fasc. 7, for the years of 1650, 1659, 1667, 1683, 1685, 1686, 1692, 1732) and fasc. 13 , for the years of 1776 and 1778 (Box 24).

33 Ildikó HORN, Csáky Anna Franciska és a pozsonyi klarisszák [Anna Csáky Franciska and the Poor Clares of Bratislava], Aetas 1992, p. 33, pp. 37-38.

34 "Kik mindazon által illyenek az orvosságok igazgatásaban S. Sophia tanácháual, ki a mennyre tüle lehet, kiualtképpen á Doctor jelen létében, tanáchát, s tehetseges iutalmas faradsághát a betegektül ne szannya." ŠAB MPF Lad. 29. Fasc. 7. 
spoke Hungarian and it was necessary to have a potential interpreter in the infirmary who could facilitate the communication with the mainly German-speaking lay practitioners. ${ }^{35}$ The same role was assigned to Sophia Kronerin in 1683 who simultaneously served as a German secretary and as an infirmarer. Two years later, a short note next to her name explicitly calls her "the interpreter of the doctor and of the surgeons". Her name appears at the first place in the list of infirmarers both in 1685 and $1686 .{ }^{6}$

Hints at apothecary knowledge - that can be regarded as a more specific expertise in healing - appear in the protocols only occasionally and under various names. A "water-burner" (vizek éghetőe) is listed after the infirmarers in Bratislava in 1650. The name of the office refers to the activity of distillation and, probably, to the preparation of medicaments as well. There is no mention of this office until 1776 when it appears again, but then there is no trace of it in the next protocol of $1778 .{ }^{37}$

Severe instructions were given to the abbess of Bratislava by the Franciscan superior, Felix Miskey ${ }^{38}$ aiming to improve the inner discipline of the community. The problems addressed by Miskey probably came to surface at the occasion of the appointment of the new superiors of the convent in $1686^{39}$ and included complaints also about the nursing of the sick. It turned out that the food given to the inmates of the infirmary was neither appropriate nor sufficient and mainly a lay sister, Agattha Sörtm ${ }^{40}$ was blamed for the conflicts emerging from the unsatisfactory treatment. Miskey ordered the abbess to handle the disciplinary affairs, including the supply of the sick. ${ }^{41}$

35 The previously bilingual community was divided into two in 1623 . The nuns were in Vienna at that time, where they escaped from the troops of Gabriel Bethlen. The German-speaking nuns decided to stay in Vienna where they moved into the building of the previous Franciscan monastery (Nikolaikloster) and only the Hungarian nuns returned to Bratislava. I. HORN, Csáky Anna Franciska és a pozsonyi klarisszák, pp. 28-29; J. KARÁCSONYI, Szt Ferencz rendjének története 1711-ig, p. 521; K. SCHWARCZ, Mert ihon jönn Aßonyotok és kezében új szoknyák, pp. 201-203.

${ }_{36} \quad$ "Sr. Sophia Kronerin. Aki a Doktor, és Borbélok tolmácsa." ŠAB MPF Lad. 29. Fasc. 7.

37 The protocol of 1776 was used as a draft for noting the changes in 1778. For this reason, several words and names are crossed out and substituted with other ones. The office of the water burner is also deleted and only the first name of the person - Agatha -is readable. A list of the nuns of Bratislava submitted to the Lieutenancy Council (Ungarische Statthalterei) for the request of Maria Theresa in 1770 mentions Agatha Lixlin lay sister who joined the convent in 1737. Her name does not appear in the appointment protocol of 1778. ŠAB MPF Lad. 29. Fasc. 13. (Box 24), MNL OL C 39 Lad. D Fasc. 40.

${ }^{38}$ Miskey became the provincial of the Marian Province first in 1671 and then in 1686. János KARÁCSONYI, Szt Ferencz rendjének története 1711-ig, 1. vol., Budapest 1923, pp. 127-128, 139.

39 Miskey signed the protocol of the superiors in 1686. Štátny archív v Bratislave - Archív Mariánskej provincie františkánov [State Archives in Bratislava - Archives of the Marian Province of the Franciscans, abbreviated as ŠAB MPF], Ladula 29. Fasciculus 7 (Box 24).

40 Her name appears as Agatha Sorlin in a protocol in 1685 and as Agatha Sörtin in 1686. She was a cook. ŠAB MPF Lad. 29. Fasc. 7 (Box 24).

${ }_{41} \quad$ 'Az Betegekre keuéß Gondviselés uagyon, auagy czak nem ßemi sem az Étekre nézue; közönséges uastagh étkekkel tartatnak; Az Étkeket Vay nélkül, Fü-ßerszámnékül, izettlenül szolgáltattyák nekik. Sőtt az kj nagyobb, az konyhához látok, nevezett szerint Soror Agattha Sörtm Layka oly irgalmattlanok czak egy kalán leuest szem akarnak adny az Naualyás Igyefogyott Betegheknek, morgas, dorgölödeß, uesekedes, Zugolodász nékül; Megh nem gondollyak, az Termésetnek Töruénnyétt, hogy tudnyllik az mit magadnak /: szükségnek idejeben :/ kiváns hogi czelekedgyenek mások, azt czelekedgyed most, más Igyefogyot Felebarátodertt." ŠAB MPF Lad. 29 (Bratislava), Fasc. 4 (Box 23). 
In 1770, the response of the convent of Bratislava to Berchtold's questionnaire described in detail the whole process of managing illness from the first symptoms to the complete recovery. After that a nun announced her illness to the abbess, she was directed into the infirmary where choir nuns were in charge of taking care of the sick day and night (Betegh-Mesternék). It was their duty to provide them the diet and medicaments prescribed by the doctor. The convent had a contract both with a physician and a surgeon. They received a fix sum annually for which they could be called to the patient whenever and as many times as it was necessary. They were allowed to enter the convent according to the rules of the constitutions that applied to such visitors. The infirmary had a chapel, too, arranged in a way that bedridden nuns could see and hear the Holy Mass from the sickroom. There was another room where convalescents could stay as long as the doctor approved their return to their everyday duties. ${ }^{42}$

According to a ground plan of the convent probably made at the occasion of the investigations, the infirmary of the convent was located on the first floor of the building. Besides the aforementioned sickroom, chapel and convalescents' room, it had a kitchen, a pharmacy and a chamber for herbs and medicine making. ${ }^{43}$

According to a supplement that reported about the furnishing of the convent, the sickroom was well-equipped with beds and necessary tools. There were cabinets, pictures, different kind of white garments for the sick, and a sufficient number of ceramic and pewter pots. ${ }^{44}$

A supplement submitted for the same investigation informs about the regular incomings and outgoings of the convent, including medical expenditures. 45 The convent

42 “Beteghes Apáczákra minden Szükséges Gondviselis Vagyon, mihent valaki Beteghsége iránt magát az elő Járonál jelenti, azontol az arra Rendelt betegh-Szobában Helyheztetik, ottan mint fekvésére , Ugy minden egyéb Szükségére alkalmatos hely vagyon, és minden Szolgálattyok meg Vagyon, mert Vannak mindenkor Rendelve Chorusi Apáczak is kik Betegh-Mesternéknek Neveztetnek, ezeknek Hivatallyok, hogy éyel-Nappal, Reájok Vigyázanak, hogy a Doctor Praescriptiojával éllyennek, hogy a Betegeknek Rendelt Gyöngébb ételek meg legyen, egy Szóval hogy őket Jgaz Szerzetes Attyafiui módon mindenben Segítségh, a Doctornak, Borbélynak füzetéssek lévén, Valamikor Szükségh, a Beteghez bé Hivatattnak, és ha Súlyos az Nyavalya Napjában töbször is, a mi módunk és Constitutjóink Szerint bé eresztettnek, ha penig agyban sinlödnek, Vagyon kápolnánk Ugy alkalmaztatva, hogy hogy az Betegh Szobábul, és ágybul is Láthattyak, és Halhattyák, a Sz[ent] Misét. Műdőn penigh Gyógyulni kezdenek Vagyon Más Szoba is a hol mint adig maradnak, még has Doctor jtéleti Szerint Eléghségesseknek tartattnak, kalastrombélj foghlalatosságiknak Véghben Vételére." MNL OL C 39 Lad. D Fasc. 40. Feölséghes koronás királné Aszonyunk eő Feőlséghe, kegyelmes Parancsolattyábul és az Feőlséghes királyi Hel-Tartó Tanácsnak kegyes Rendelésséból M[é]1[tósá]ghos és Feő Tisztelendő Püspök Gróff Berchtold Ferencz eő Nagyságha által, Szűz Szent Clara Szerzetén Lévő Posonyi Conventnek Irásban bé Adatott Punctumokra Ugyan emlétett Convent Részéről Való feleletek, f. 228r-v.

43 Neither the exact date nor the name of the architect is indicated on the two ground plans of the convents of Bratislava and Buda. They were preserved in the same bundle as the investigation reports of 1770. The bundle also contains documents about the regulation of the convents in 1773. MNL OL C 39 Lad. D Fasc. 40. Entwurf derer Grund-Rissen deren W. W. E. E. Kloster-Frauen S. Clarae in Pressburg, f. 340 .

44 “Az Betegh Házban Vagyon elegendő Ágy, hozá Valo eszközzel edgyüt, olmáriumok, jrot képek, Ugy nem külömben a Beteghek Szükséghire minden Némő fejér Ruha, ón, és Cserép edényekis. Mennyire kivántatik elegendő vagyon." MNL OL C 39 Lad. D Fasc. 40, f. 259 r.

45 The annual average expenditure was calculated for each item from the invoices of the previous three years (i.e. 1767, 1768 and 1769). 


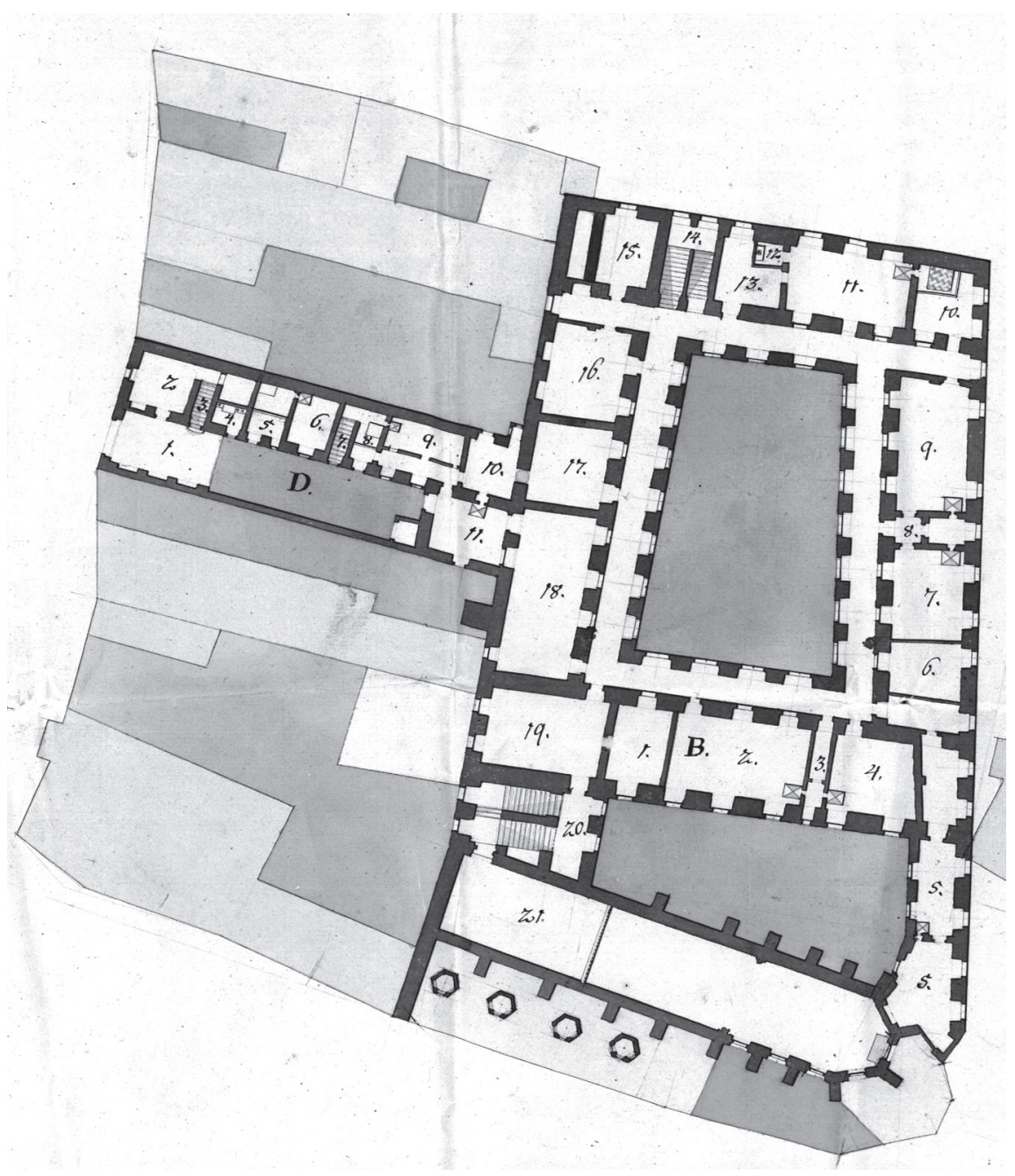

Fig. 1. Ground plan of the convent of Bratislava. First floor.

spent $441 \mathrm{fl} 2 \mathrm{x}$ on medicaments, the surgeon received $56 \mathrm{fl}$ for his services. The doctor's annual salary was 50 fl. ${ }^{46}$

\section{Trnava}

Similarly to the convent of Bratislava, the earliest documents informing about an infirmary in Trnava are the protocols reporting about the appointment of infirmarers

${ }_{46}$ MNL OL C 39 Lad. D Fasc. 40. Akar minémű Jovedelmek találtassanak..., f. 273r. 


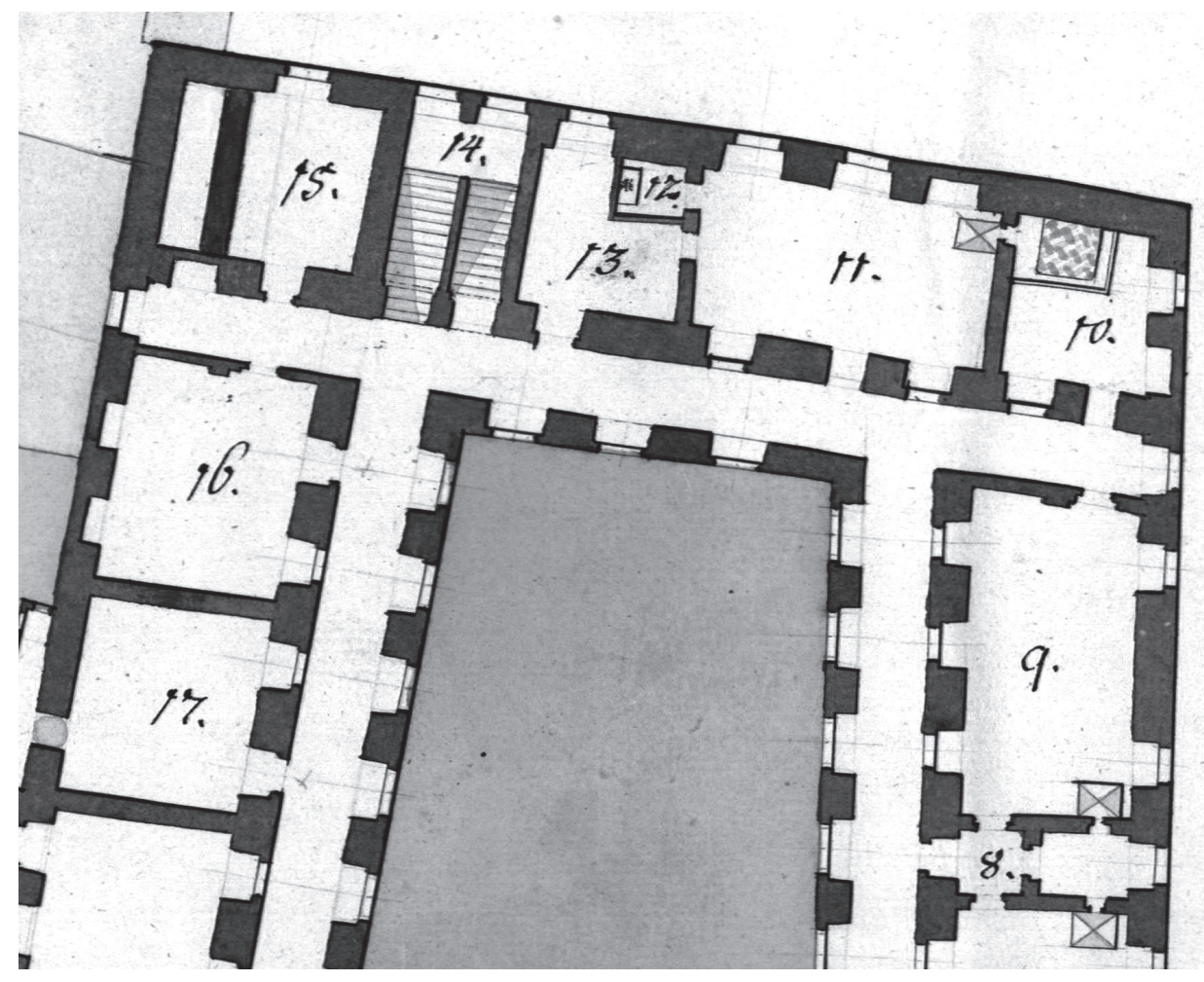

Fig. 2. The rooms of the infirmary are marked with the numbers 9-16 in the following order: room of the convalescents (9), kitchen of the infirmary (10), sickroom (11), chapel (12), pharmacy (13), (staircase, lavatory), a chamber for herb or medicine making (16).

from 1668.47 The names - just like in Bratislava - change rather often and only indirect evidence can hint at the inner hierarchy and expertise of the infirmarers.

Two apothecaries (patikárosnék) are listed besides the infirmarers in 1691: Eufraxia Osváld and Innocentia Czatárj. Their careers can be traced through various offices. Soror Eufraxia was among the infirmarers already in 1668 and she held the same office in 1672 when she was also listed as a gardener. Besides her apothecary title in 1691, she is named as a gardener again that hints that the herbs necessary for the medicaments could be produced in the garden of the convent. The other apothecary nun, Innocentia Czatárj was mentioned also among the infirmarers in 1691. In 1694, four nuns were named as "apothecaries and gardeners", including Innocentia. She was among the infirmarers in 1696, she was gardener in 1699 and infirmarer again in 1700, 1716 and in $1725 \cdot \cdot^{48}$

47 ŠAB MPF Lad. 30. Fasc. 6, for the years of 1668, 1672, 1691, 1694, 1696, 1697, 1699, 1700, 1701, 1702, 1707, 1709, 1710, 1716, 1725, 1725, 1728, 1731, (1770?), 1780 (Box 27).

48 ŠAB MPF Lad. 30. Fasc. 6 (Box 27). 
A new, relatively lasting position was established in 1699: Martina Antal was appointed to the position of the "guardian and apothecary of the infirmary" (Beteg haz gondviselöje és Patikariussa). She had already had several years of experience in nursing and healing. Her name appears for the first time in 1672 when she was a cook (konyha Mester). Since the diet of the sick often had to be different from the meals of the healthy nuns and the making of medicaments could also overlap with cooking techniques, the cooperation between infirmarers and cooks could be quite common. Almost two decades later, Soror Martina was listed among the infirmarers in 1691 and then in 1694. It could be also an opportunity for her to learn from the aforementioned two apothecary nuns. Soror Martina's name is missing from the next two protocols $(1696,1697)$ and it reappears with her new title in 1699 . She is listed as the guardian of the infirmary until 1707, then there is no more information about her. 49

A new apothecary (Patika gondviselo) appears in 1710: Anna Maria Hajlovics. Interestingly, unlike the aforementioned apothecaries, her appointment was not preceded or followed by any service for the infirmary: she was sacrist in 1709 and porter in 1716 . Her name was not listed among the infirmarers either. ${ }^{\circ}$

The term Apatekariusnék appears in the protocols of Trnava in the 1770's. For the first sight, it seems to mean female apothecaries, but taken into consideration that four names are listed in this category and no infirmarers are mentioned in the protocol, the term probably referred to everybody who was in charge of caring the sick..$^{11}$

The response of the nuns to Galgózy's questionnaire submitted in 1770 referred to a doctor with whose services were ensured for the convent with a contract and whose prescriptions was completed with all the care and supply the community could provide. The abbess, Rosalia Perényi also added that the sufficiency of care could be proved with the invoices of the apothecary, too. ${ }^{52}$ The convent paid annually 50 fl for the services of the physician, and $30 \mathrm{fl}$ for the surgeon (chyrurgus). ${ }^{53}$

A more precise picture unfolds from the dissolution files made in 1782. Similarly to the Poor Clares' nunnery of Bratislava, the infirmary in Trnava also consisted of functionally differentiated rooms that constituted a separate unit in the building. The rooms of the infirmary opened from the same corridor as the refectory and the kitchens. In the direct vicinity of two chambers storing kitchen equipment and food, a third room was probably fulfilling the function of a storage room, too, but its furnishing and equipment shows more connection with the sickrooms that were located nearby. The next room was the so-called "summer infirmary" that could be the place for preventive venesections, carried out mainly in the summer months. In addition, the commission-

\footnotetext{
ŠAB MPF Lad. 30. Fasc. 6 (Box 27).

ŠAB MPF Lad. 30. Fasc. 6 (Box 27).

ŠAB MPF Lad. 30. Fasc. 6 (Box 27).

52 "Betegségünk idéjén pedig Vagyon Conventünknek Conventios Doctora, akinek Praescriptioja szerint orvosoltatunk Minyájan, a hoz minden Apolgatás, mind ételben, és italban való szűkséges gondviselés, és szolgálat minden fogyatkozás nélkül meg vagyon.Bizonyétanni fogiak a Patikak eszetndőnként valo Auszeugalissai." ŠAB MPF Lad. 30. Extra ordinem no. 5 (Box 28).

53 Galgóczy's report was preserved in two copies. MNL OL C 39 Ladula D, Fasciculus 40. and ŠAB MPF Lad. 30. Extra ordinem no. 4 (Box 28). Unfortunately, the bills of the pharmacist mentioned by the abbess were not included into or attached to any of them.
} 
ers listed the acid chamber, from which they proceeded into the bigger infirmary, the chapel, the smaller infirmary and the infirmary kitchen. ${ }^{54}$

47 nuns lived in the convent of Trnava at the time of its dissolution ${ }^{55}$, while its infirmary could accommodate the maximum of ten to twelve sick persons: there were two beds in the summer infirmary ${ }^{56}$, seven litters with matrasses, pillows, mats and paillasses in the bigger sickroom, ${ }^{57}$ and three in the smaller one. ${ }^{8}$ Although the number of beds can inform about the size and capacities of the infirmary, it is important to note that the medical activities taking place there served most probably the whole community, not only those whose stay in the sickrooms became necessary due to their physical incapacities. For this reason, even if the sickrooms and the chapel appeared to be the most representative spaces of the infirmary with a special spiritual function, the neighbouring rooms - seemingly fulfilling only auxiliary functions - also deserve attention and a detailed analysis.

As it has been mentioned, the first room that belonged to the infirmary was not labelled with any specific function by the commissioners. The items listed in the inventory do not hint at any daily activity that could take place there, but seem to indicate a rather "passive" usage. Some pieces of furniture, namely nine smaller and bigger benches made of planks, two wooden tables, a small wooden footstool and two chairs were listed in the inventory ${ }^{59}$, but it is unclear whether they were really used or only stored there. The rest of its furnishing was suitable to fulfil a storing function: the inventory mentions a wooden chest with five drawers in which various things were kept

54 MNL OL C 103 - Poor Clares' convents - Trnava - Inventarium Anno 1782 Die vero $18^{\mathrm{a}}$ et sub seqvis tam Mensis Aprilis, quam et May Diebus in Libera Regiaqve Civitate Tyrnaviensi I[nclyto]. Co[mi]t[a] tui Posoninen[si] ingremiata Mobilium, ac Imobilium et Universae Supellectilis profanae ad Claustru[m] et Conventum aboliti Religiosi Ordinis Sanctae Clarae Monialium Virginum Tyrnaviensem antehac pertinentium, et in eodem Repertarum per Nos infrascriptos tam ex Parte Status Politici, quam et Excelsae camerae Hungarico Aulicae denominatos Comissarios Regios modo et ordine seqventibus peractum, ff. 85r-87r (Box 32).

55 Magyar Ferences Könyvtár és Levéltár, Kézirattár, Jakosics Gyüjtemény [Hungarian Franciscan Library and Archives, Jakosics' Collection of Manuscripts], 1. vol., pp. 130-131.

56 “1. Lectus cum superficie / 1. Praeterea Lectus Sine Superficie” MNL OL C 103 - Poor Clares' convents - Trnava - Inventarium Anno 1782..., f. 85v (Box 32).

57 “6. Lecticae Cum Tecto et Lectisternijs / 1. Lectica sine tecto Cum Lectristernijs tamen quae lectisternia universim consistunt, et Mattis 11. Pulvinariubus 17. Madracis 3. Stramineis Saccis 4. Linteaminibus 3. et Culcitris 2." MNL OL C 103 - Poor Clares' monasteries - Trnava - Inventarium Anno 1782..., f. $86 \mathrm{r}$ (Box 32). It is noteworthy that the inventory refers to beds in the cells of the nuns as lectus, while it mentions mainly lectica, i.e. litters in the infirmaries that probably functioned also as beds, but simultaneously could be suitable to move disabled persons. For the comparison with the nuns' cells see MNL OL C 103 - Poor Clares' monasteries - Trnava - Inventarium Mobilium et rerum Monialium prorpiarum, ff. 188-200.

58 "3 Lecticae Caeruleae Cum Madracis duabus, Saccis stramineis tribus, pulvinaribus vero duobus inveniunt[ur]" MNL OL C 103 - Poor Clares' monasteries - Trnava - Inventarium Anno 1782..., f. 87r (Box 32).

59 “2 Mensae Ligneae /.../ 9. Scamna assericea majora et minora / 1. Scabellum assericeum” MNL OL C 103 - Poor Clares' convents - Trnava - Inventarium Anno 1782... f 85r. "1 Sedes ex pelle cum Lateribus et appodiatoris / 1. Sedes pure lignea Cum Lateribus et appodiatorio” MNL OL C 103 - Poor Clares' convents - Trnava - Inventarium Anno 1782..., f. 85v (Box 32). 
in several small boxes ${ }^{60}$. Unfortunately, it is not specified what they contained, and the content of further three small chests of drawers, three cabinets, and three chests made of planks ${ }^{61}$ remained unlisted, too. Consequently, it is not possible to discern whether they contained materials, medicaments or any kind of instruments that were used for healing and that could further specify the function of the room. However, the inventory provides evidence that herbs were processed and stored in the room: it lists a chest, two knives and a tree stump chopping block used for processing and storing herbs. ${ }^{62} \mathrm{~A}$ wooden double ladder could facilitate the hanging and accessing of the drying herbs. ${ }^{63}$

The room also contained objects that were used only occasionally and implied a different spatial context, i.e. they were applied in practices that took place in other parts of the monastery. One of these objects was a catafalque. The rituals of mourning usually started in the sickroom when the nuns assembled around their dying fellow and prayed together. The moment of death and the preparation of the corpse for the funeral was also accompanied with prayers and singing that also took place in the infirmary. ${ }^{64}$ The catafalque must have been used as a raised bier that was also suitable for carrying the dead into the church where the funeral mass took place.

There were further objects that could belong to the sickrooms, but they were taken there only when it became necessary. This could be the case of the five commodes or of two copper instruments used as warming-pans for the beds. ${ }^{65}$

Several instruments were found in the room that were related to different operations around a stove, although the inventory does not mention either heating or cooking facilities. For this reason, the dipods, tripods, forceps, pots, lids, hooks, scoops, pincers listed in the room ${ }^{66}$ were most probably not used, but only stored there. There

6。 “1. Armarium Ligneum, Cum qvinque Subladis pro Conservandis diversae speciei rebus supra qvod Capiosiores Scatulae Collocarae habentur" MNL OL C 103 - Poor Clares' monasteries - Trnava - Inventarium Anno 1782..., f. 85 r (Box 32).

61 “3. Praeterae Lignea minora Armaria Cum Subladis / 2 Insuper Armaria adhuc minora Sine Subladis /.../ 1. Armarium Viride Cum Ligneis Craticulis ad instar Mensae /.../ 3. Fiok assericea" The chests were referred to with the Hungarian word fiok. MNL OL C 103 - Poor Clares' convents - Trnava - Inventarium Anno 1782..., f. 85r-v (Box 32).

62 “1. Lignea Cista pro herbis" MNL OL C 103 - Poor Clares' convents - Trnava - Inventarium Anno $1782 . . .$, f. 85r. "1. Truncus Cum pedibus pro Consecandis herbis /.../ 2 cultri pro Consecandis herbis unus major alter minor" MNL OL C 103 - Poor Clares' convents - Trnava - Inventarium Anno 1782..., f. $85 \mathrm{v}($ Box 32).

63 “1. Scala duplicara Lignea” MNL OL C 103 - Poor Clares' convents - Trnava - Inventarium Anno $1782 . . .$, f. $85^{\mathrm{r}-\mathrm{v}}$ (Box 32).

64 "1. Mortuorum Tumba Cum pedibus Ligneis pro deportandis ad Sepulchrum mortuis Cadaveribus deserviens" MNL OL C 103 - Poor Clares' convents - Trnava - Inventarium Anno 1782... f 85r (Box 32)

65 “4. instrumenta assericea S[ub] V[erbo] Leibstul dicta” V MNL OL C 103 - Poor Clares' convents Trnava - Inventarium Anno 1782... f 85r. "Instrumentum aeneum Leibstul dictum / 2 Cuprea Instrumenta pro Calefaciendis Lectis” MNL OL C 103 - Poor Clares' convents - Trnava - Inventarium Anno $1782 . . .$, f. $85 \mathrm{v}$ (Box 32).

66 “1. Instrumentum ex asseribus penes fornacem Collocati solitum / 1. Praeterea Instrumentum Ligneum pro Balneo deserviens /.../ 1. Instrumentum Ligneum pro Conservandis Ollis / 4. Fer[r]eae Paleae/ 1. Fuscinula fer[r]ea /3. Instrumenta fer[r]ea pro deportandis Carbonibus / 1. Forceps fer[r]eus / 1. Uncus fer[r]eus / 4. Bipodes fer[r]ei / 2 Tripodes fer[r]ei /.../ 2 Instrumenta fer[r]eain fornia Cacaborum pro excoqvendis diversis succis / 3. opercula / Cuprea / 2 Opercula fer[r] ea / 1. Scala duplica- 
were also two pots dedicated for the making of plasters and two further instruments for preparing of extracts. ${ }^{67}$ These objects could be used either in the kitchen of the infirmary or in the acid chamber as the latter one also had a stove with a built-in pot. The kitchen was rather small and the commissioners did not list anything else in it, but two copper pots used for making spirits. ${ }^{68}$ Its size could make it also necessary to store the instruments at another place. However, the presence of these objects, even if they were dispersed among different rooms, hint at the production of medicaments inside the monastery with similar means as in the workshops of apothecaries.

In the summer infirmary, medicine-related objects were stored in a more decorative setting. Three gilded cabinets with green curtains provided storage place for medical instruments, while two further, simpler cabinets contained "burned" spirits. ${ }^{69}$ The instruments were most probably surgical tools used for the aforementioned practice of preventive phlebotomy. The summer infirmary had no heating and its equipment hints that it was rather a place for those who were able to sit and move. The litters used as beds could be also carried there when the weather was warm enough. However, at the time of the making of the inventory - i.e. from mid-April until the end of May - the two "summer gates" of the refectory - that were probably wooden frames with a mosquito net - and one more for the summer infirmary were still waiting for the warmer weather inside the room. ${ }^{70}$

Besides the two beds mentioned earlier, the rest of the furnishing consisted of two long tables, five smaller tables, a bench made of planks, five chairs with handles and footrests, two small, green cabinets, two smaller chests, ${ }^{71}$ and a travel trunk. ${ }^{72}$ The walls were decorated with two pictures: one of them represented the crucifixion, while the other one was an image of Mary, holding the little Jesus in her arms.73

ra Lignea / 1. Storea / 1. Instrumentum Setaceum cum lignes manubris" MNL OL C 103 - Poor Clares' convents - Trnava - Inventarium Anno 1782..., f. 85r-v (Box 32).

67 "2 Cacabi pro Conficiendis emplastris /.../ 2 instrumenta ferrea in forma Cacaborum pro exoquendis diversis Succis" MNL OL C 103 - Poor Clares' convents - Trnava - Inventarium Anno 1782..., f. 85v (Box 32).

68 “2 Cacabi Cuprei pro exurendis spiritibus deservientes” MNL OL C 103 - Poor Clares' convents Trnava - Inventarium Anno 1782... f 87 r (Box 32).

69 “3. Armaria inaurata in quibus Instrumenta pro medicinis asservari consveverunt, Cum viridibus Cortinis / 2 Praeterea Armaria Assericea ad qvae diversi exusti Spiritus Collocari Solent" MNL OL C 103 - Poor Clares' convents - Trnava - Inventarium Anno 1782..., f. 85v (Box 32).

$70 \quad$ "2 Portae aestivales ad refectorium applicavi solitae 1. Porta aestivalis ad infirmariam aestivalem aplicavi solita." MNL OL C 103 - Poor Clares' convents - Trnava - Inventarium Anno 1782..., f. 86r (Box 32).

${ }_{71}$ "2 Mensae longiores qvarum una viridis est Cum qvinqve Subladis, 5 Praeterea Mensae Minores, 1. Scamnum asseraceum 4. Sedes cum manubrijs et apodiatorijs ligneae" MNL OL C 103 - Poor Clares' convents - Trnava - Inventarium Anno 1782... f 85v. “1. Sedes ex pelle Cum manubrijs et appodiatorio /.../ 2. Minores Cistae Ligneae 1. Armarium minus viride Cum Subladis 1 Armarium minus viride Sine Subladis" MNL OL C 103 - Poor Clares' convents - Trnava - Inventarium Anno 1782..., f. $85 \mathrm{v}-86 \mathrm{r}($ Box 32$)$.

72 "1. Cista Kupfen dicta" - The chest named as "Kupfen" probably referred to a Koffer, in German. MNL OL C 103 - Poor Clares' convents - Trnava - Inventarium Anno 1782..., f. 86r (Box 32).

73 "6. Theses Chartaceae cum Listis 1. Chartacea Thesis sine Lista 1. Imago Crucifixi ex Tela Cum Listis Caeruleo albis ligneis 1. Imago Beatae Matris Jesulum in ulnis tenentis” MNL OL C 103 - Poor Clares' convents - Trnava - Inventarium Anno 1782..., f. 86r (Box 32). 
The acid chamber opened from the summer infirmary. It was equipped with two shelves for storing the acids, on which seven small pots were kept, while eight further ones were in a storage bench at the stove. It is unknown what was stored in the further three cabinets of the room. The rest of the equipment consisted of two tables, four chairs, a footstool, a ladder, a lamp and two candlesticks. ${ }^{74}$

The bigger infirmary could be accessed through the acid chamber, while it was also open towards the chapel of the infirmary. As it has been mentioned, it was suitable to accommodate seven sick inmates. One bigger and two smaller tables with nine chairs could make it possible for them to consume their meals in the infirmary. 75 Its function also blended into the role of a sacristy to some extent. In a cabinet with three drawers, valuable textiles were stored, mainly of liturgical function: eight big linen altar clothes, a curtain for the gate of the infirmary, a bedspread made of barracan, ten chalice veils, an antependium woven from golden and white threads and decorated with additional colouring and eight tablecloths. ${ }^{7}$ Another cabinet contained more common kind of textiles connected to the sickroom function: smaller tablecloths, napkins, bedclothes and towels. ${ }^{77}$ The room was decorated with several images, but the commissioners described only the base material (paper, canvas) and the frame of the pictures without mentioning what they actually depicted.

The chapel opened from the bigger infirmary that enabled bedridden nuns to listen to the mass even in a very weak condition. The altar was dedicated to the Holy Cross and represented the passions of Christ. It was equipped with a wooden cross, three missal tablets with prayers covered with glass, a silk or brocade antependium with silver tassels, a small pillow, a missal book and two bells. Three pictures were inventoried above the altar, and two bigger and two smaller ones on its sides. ${ }^{78}$

74 “2. Armaria Cum Cratibus Ligneis Supra qvae unum appendiculum etiam ligneum est. /2. Pegmata Lignea pro Conservando aceto in qvibus septem Vascula, Octavum vero ad fornacem in scamno Collocatum Cum aceti Ur[ceatim?] Cir[ca?] 5. habetur. / 2 Mensae /3. Ligneae Sedes cum Lateribus et dorsali appodiatorio / 1 Lignea Sedes ordinaria / 1. Armarium viride mediocre Cum $3^{\text {bus }}$ Subladis / 2 Candelabra aenea / 1 Lampas ex Stanno / 1. Scabellum Ligneum Parvum / 1. Scala MNL OL C 103 Poor Clares' convents - Trnava - Inventarium Anno 1782..., f. 86r (Box 32).

75 "1. Mensa major / 2. Mensae Majores / 4 Sedes ex pelle Cum Lateribus, et appodiatorijs / 2 Sedes ex pelle sine Lateribus, et appodiatorijs / 3. Sedes pure ligneae Lateribus, et appodiatorijs" MNL OL C 103 - Poor Clares' convents - Trnava - Inventarium Anno 1782..., f. 86v (Box 32).

${ }_{76}$ "Armarium cum tribus Subladis in Cuius Sublada Superiori 8. Majora Linteamina pro Tegumento Ara. 1. Cortina ad portam Infirmariae deserviens 1 Linteamen ad Lectum ex Materia Parkan 10 Linteamina minora infra Calicem sterni solita In eiusdem Armarij Sublada 1. Antependium ex Tela partim flava, partim incolorata alba ad altare Collocavi solitumIn tertia eiusdem Armarij Sublada 8. mappae mensales" MNL OL C 103 - Poor Clares' monasteries - Trnava - Inventarium Anno 1782..., f. 86v (Box 32).

779 minores mappae, 6 mappulae, 7 Coopenticula pro Mattis, 13 Coopenticula pro Pulvinaribus, 6 Mantilia. MNL OL C 103 - Poor Clares' monasteries - Trnava - Inventarium Anno 1782..., f. 86v (Box 32).

${ }_{78}$ "Capella ad qvam ex Infirmaria majori aditus patet fornita cum duabus majoribus fenestris una Porta bifariata, infernis ex asseribus superius vero ex vitro Constructa provisa est in qua Capella datur unum altare Sanctae Crucis Cum integra [Chris]ti Domini passione supraq[ue] idem tres imagines ex Tela cum Listis Caeruleis interne modicum inauratis Collocatae habentur, est praeterea in eodem altari unus Crucifixus Ligneus tres Tabellae Myssales, Cum orationibus Sub vitro unum antipendium variegati Coloris ex Atlas Cum fimbreis argenteis unus pulvillus, et Liber Myssales duae Campanilae, in Lateribus aurem Parietis duae imagines majores duae vero minores ex Tela diversas figuras in se 
The smaller infirmary was located in the vicinity of the bigger one. It was a heatable room with three beds that was also used to store herbs and other things in three built-in cabinets.79 The rest of the furniture consisted of a fourth, empty cupboard and seven different chairs. ${ }^{80}$

\section{Zagreb}

The Poor Clares' convent of Zagreb had 22 inmates at the time of the dissolution. ${ }^{81}$ The sick members of the community were nursed by the 22-year-old novice, Francisca Handtin. She came from Bohemia and she had been living in the Order of Saint Clare for already 4 years. ${ }^{82}$ The monastery had a sickroom (infirmaria) with four beds. ${ }^{83}$ Its furnishing consisted of four chests, a broken cupboard, one bigger and two smaller tables, two footstools, and a chair. Furthermore, two warming-pans, a tin washbasin, two big, green jars and two larger glasses were inventoried. It was decorated with several smaller images and with a statue of the Virgin Mary. This rather modest room was not suitable for the celebration of the Eucharist, but there were three breviaries that could be used by the nuns who couldn't participate in the praying of the Liturgy of the Hours because of their illness. ${ }^{84}$ The production or the storing of medicaments in the infirmary cannot be evinced, but a pair of drinking plates for chocolate found in the room can indicate the consumption of chocolate with a medical purpose..$^{85}$

continentes" MNL OL C 103 - Poor Clares' convents - Trnava - Inventarium Anno 1782..., ff. 86v-87r (Box 32).

79 “3. Ibidem Armaria imurata pro herbis et alijs Rebus recondendis deservientia" MNL OL C 103 - Poor Clares' convents - Trnava - Inventarium Anno 1782..., f. 87r (Box 32).

8o “1. Praeterea Armarium Viride Vacuum / 1. Sella ex Pelle Cum Lateribus et appoditario / 1. Praeterea Sella ex pelle sine lateribus et appoditario / 1. Sella ex panno Viridi Ordinario Cum Lateribus et appoditario / 2. Sellae Ligneae cum Lateribus et appoditorio / 2 Sedes aeque ligneae nonnisi Cum appodiatorio." MNL OL C 103 - Poor Clares' convents - Trnava - Inventarium Anno 1782..., f. 87r (Box 32).

81 MNL OL C 103 - Poor Clares' convents - Zagreb - Declaratio M[ater] Abbatissae et Sororum professarum Monialium de futuro Vitae Statu facta; Declaratio Franciscae Handl non professae; Declaratio non professarum Monialiu[m] de futurae Vitae Statu, ff. 87r-9ov (Box 32).

82 MNL OL C 103 - Poor Clares' convents - Zagreb - Tabella. Sanctimonialium aboliti Ordinis S[anctae] Clarae in Claustro Zagrabien[si] hac tenus residentium fine eo elaborata, ut Clementer Applicidata Diurnalis pensio cum aliis competentiis Accuratius assignari et dependi possit, horsum inducta, f. $83 \mathrm{v}$ (Box 32).

$8_{3}$ “4. Spondae, quarum una ex ligno nucis / 4. Culcitrae / 4. Pulvinaria” MNL OL C 103 - Poor Clares' convents - Zagreb - Inventarium Mobilium Religiosam Communitatem Suppressi Claustri Sanctimonialium Zagrabiensium olim Concernentium infraspecificatis diebus Mensis Aprilis 1782. modo sequenti adornata, et quidem..., f. 48r-v (Box 32).

84 "In Cubiculo Infarmariae / Sub No $7^{\text {[mo] } / 17 . ~ I m a g i n e s ~ i n ~ t e l a ~ p i c t a e ~ / ~ 5 . ~ I m a g i n e s ~ p a p i r a c e a e ~ / ~ 4 . ~ C i s t a e ~}$ / 3. Mensae, una major, duae minores / 2. Scamna / 1. Sella inclinatoria attritae / 1. Candelabrum Lamineum / 1. Lavatorium Stanneum / 1. Par Fialarum pro Chokoladi / 3. Breviaria / 2. Amphorae majores virides / 2. Vitra majora / 1. Statua B[eatae] V[irginis] M[ariae] / 3. Imagines parvae in vitris /.../ 1. Tegumentum vulgo Guny / 2 Instrumeta cuprea pro calefaciendis Lectis vulgo Skandalet / 1. Porta aestiva sua sera provisa / 1. Armariolum confractum" MNL OL C 103 - Poor Clares' monasteries - Zagreb - Inventarium Mobilium Religiosam..., f. 48r-v (Box 32).

85 Donatella LIPPI, Chocolate in History: Food, Medicine, Medi-Food, Nutrients 5, 2013, 1573-1584. 
A closer look at the financial liabilities of the monastery can reveal other ways in which it was supplied with medicaments: it acquired them from nearby pharmacists. The monastery was located in the so-called Upper Town of Zagreb (Gradec), i. e. in the fortified free royal city that developed independently from the Capitulum (Kaptol), the neighbouring canonical settlement of the episcopal seat. The dissolution files of the Poor Clares still refer to them as two separate settlements, as they became integrated only in the nineteenth century. The invoices submitted by pharmacists both from the Upper Town and from the Capitulum inform us about the medical expenditures of the monastery from the years of 1781 and 1782. They reveal that the nuns availed themselves more often of the "local" pharmacy in the Upper Town. They owed its pharmacist, Karl Fröschl, 25 of $19 x$ for the medicaments they received in 1781 and $112 \mathrm{f} 46 \mathrm{x}$ for the apothecary products provided to them until April 1782. ${ }^{86}$ The nuns acquired medicaments from Johann Jürgen, the pharmacist in Kaptol for $51 \mathrm{f} 22 \mathrm{x}$ in 1781 and for 2 fl $6 \mathrm{x}$ in $1782 .{ }^{87}$

\section{Buda}

The response of the Poor Clares of Buda to Berchtold' questionnaire informs about a similar procedure as it has been presented in the case of Bratislava: when a nun reported herself sick, she was laid down in the infirmary and nursed according to the prescriptions of the doctor of the convent. Nevertheless, there is a new element in the report, as it also describes the personnel and inner hierarchy of the infirmary: the head of the infirmary was always an older nun who could rely on the assistance of six further convent members. That was regarded as the necessary number of nurses to prevent problems that could evolve from insufficient attention. ${ }^{88}$ Another supplement of the report of 1770 lists the name of each nun who entered the convent and the dowries they offered for it. Some of the nuns were accepted without a dowry, but with the expectation that they

86 Karl Fröschl submitted a detailed invoice listing not only each medicament, but also the name of the nun who received it. MNL OL C 103 - Poor Clares' convents - Zagreb - Specification der Medicamenten / Welche für die Wohl Ehrwürdigen Frauen des Ordens der Heiligen / Clarae aus der alhiesigen oberen stadt Apotheker sind verabfolget werden / Anno 1782, ff. 65-68, Specification der Medicamenten / Welche für die Wohl Ehrwürdigen geistlichen Frauen des Ordens der H[eiligen] Clarae aus der alhiesigen Stadt Apothecke sind verabfolget werden als. / Anno 1781, ff. 140-149 (Box 32).

87 Johann Jürgen's invoice was similarly rich in details. MNL OL C 103 - Poor Clares' convents - Zagreb Medicamenten welche für das Löbl[iche] Convent der Ehrwürdigen Kloster Frauen auß den Orden der Heil[igen] Clara zu Agram in Croatien, auß der Apotheke im dohm Kapitl verabfolget sint worden, f. 150 .

88 “A Beteges Apáczákra minden Szükséges gondvisellés Vagyon, mikor valamellyik magat az Elöl-Járónal betegsége erránt jelenti, azonnal az arra rendeltetett Különös Betegek Szobájába helyheztettetik, Ottan mid fekvésére, mind nyugodalmára, és egyéb Szükségére alkakmatos hely Vagyon, meg vagyon nékik minden féle szolgálattyok, mert Vagyon rendelve egy az öregebb apáczák közül, aki mindenre gondot Visell, mind ételekre, italokra, a Doctor Praescriptioja szerint azon kivül kiváltképpen az orvosságok rendelt bé vételire, Sőtt azon fö Gonvisellő Apácza mellé még más hatan vannak, rendelve, a kik rend szerint maid Szolgálnak, maid Vigyáznak a Betegek körül, ugy hogy semmi veszedelmek valamely gondviseletlenség által ne következzen. Vagyon kápolnájok, a hol Szent Miset halgatnak, egy Szóval minden Provisio készen vagyon, a mellyek vagy az égesség visza terétésére, Vagy elékezvén Utolsó Orájok, a Boldog Örökkén valoságra Segéthetik Öket." MNL OL C 39 Ladula D Fasciculcus 40, f. 128r. 
will contribute to the operation of the convent with their skills that was also noted in the list. Besides organists and singers, women with surgical skills are also mentioned: Apollonia Veinhortin entered the convent in 1756, Cajetana Treszterin in 1762 thanks to her medical skills. ${ }^{89}$ In 1782, the dissolution files do not mention Soror Cajetana any more, but they inform about Soror Apollonia (Anna Weinhartin) who was responsible for the nursing of the sick. The 45-year-old nun was already seriously ill and most probably, a young novice, the 24-year-old Soror Nepomucena (Eleonora Majerhofferin) was expected to become her successor in the long run. According to the notes of the commissioners, Soror Nepomucena was also a "learned surgeon" (gelehrte Chyrurgin) and after the abolition of the Poor Clares, she wanted to join the convent of the Saint Elisabeth Order in Bratislava. ${ }^{90}$ Nevertheless, she faced several obstacles because of her novice status: while the professed nuns of the dissolved monasteries were encouraged with the promise of a higher pension to join the religious orders providing medical care or education, the novices were expected to leave the convent with a lump sum of $150 \mathrm{fl}$ in four weeks. ${ }^{91}$ But unlike the other nurse-novice, Francisca Handtin in the monastery of Zagreb, Soror Nepomucena had reached the age 24 in January 1782 that was the generally prescribed age limit for taking a monastic oath in the Habsburg territories..$^{92}$ Using this as an argument, she wished to be treated according to the same conditions as the professed nuns, but her appeal was probably not successful: she had to leave the monastery by the same deadline as other novices ${ }^{93}$ and a report written in September 1782 and listing the allocated pensions of the nuns does not contain her name either. 94

The report submitted by the convents at the order of Berchtold in 1770 provides a more detailed description of the rooms and furnishing of the infirmary. It consisted of two rooms, a kitchen and an antechamber. There was an altar in the bigger room that enabled the sick nuns to listen to the Holy Mass. The rest of the furnishing consisted of

89 MNL OL C 39 Ladula D Fasciculcus 40, f. 266v. Another list annexed to the report informs about the nuns' country of origin and reveals that Soror Apollonia was born in Hungaray and Soror Cajetana in Austria. Ibid., f. 268r-v.

go "Diese Person wäre in Rüksicht dessen, daß sie bereitsam am $9^{\text {ten }}$ Januar[i] h[oc] a[nno] das $24^{\text {te }}$ Jahr zurück geleget, mithin der vorgeschriebene Professions Zeit erreicht hatte, als eine würd[ige] professin anzusehen, und nun die verbreitete Nachricht von der erfolgen sollenden Aufhebung dieses Ordens, ist an sothanen Aufschub Ursach gewesen; Und da sie auch weiters hin geistlich leben will; so bittet sie um die Erlaubniß, zu Preßburg in den Elisabethiner Order tretten zu dürfen." According to the same report, she was the daughter of a burgher of Buda and she lived in the convent already since the age of 20. MNL OL C 103 - Poor Clares' convents - Buda - Consignation deren in dem abolirten Offner Clarissen Closter..., f. 9v (Box 31).

${ }_{91}$ M. VELLADICS, A II. József korabeli szerzetesrendi abolíció müvészettörténeti vonatkozásai, pp. 240-247.

$9^{2}$ Derek BEALES, Joseph II. and the Monasteries of Austria and Hungary, in: Nigel Aston (ed.), Religious Change in Europe 1650-1914, pp. 161-184, see p. 168.

93 MNL OL C 103 - Poor Clares' convents - Buda - Nota / A Numero $38^{\text {vo }}$ usq[ue] N[umerum] $43^{\text {tium }}$ sunt insertae, Sex illae non Professae Virgines, quae ad exigentiam Altissimi Mandati Caesareo-Regij Die 10 ${ }^{\text {ma }}$ Maij 1782 e Claustro discedere debuerunt..., f. 6gr (Box 31).

94 MNL OL C 103 - Poor Clares convents - Buda - Tabella / Exhibens specificam Deductionem, qvalem nam aboliti Conventus Monialium Clarissarum Budensium Individua cum altissimo Indultu Cae[sare]o Regio e Claustro egressa vitae statum amplexa sint? ubi commorabuntur? Et penes qvalem Cassam iisdem Pensiones assignari possent? ff. 379-382 (Box 31). 


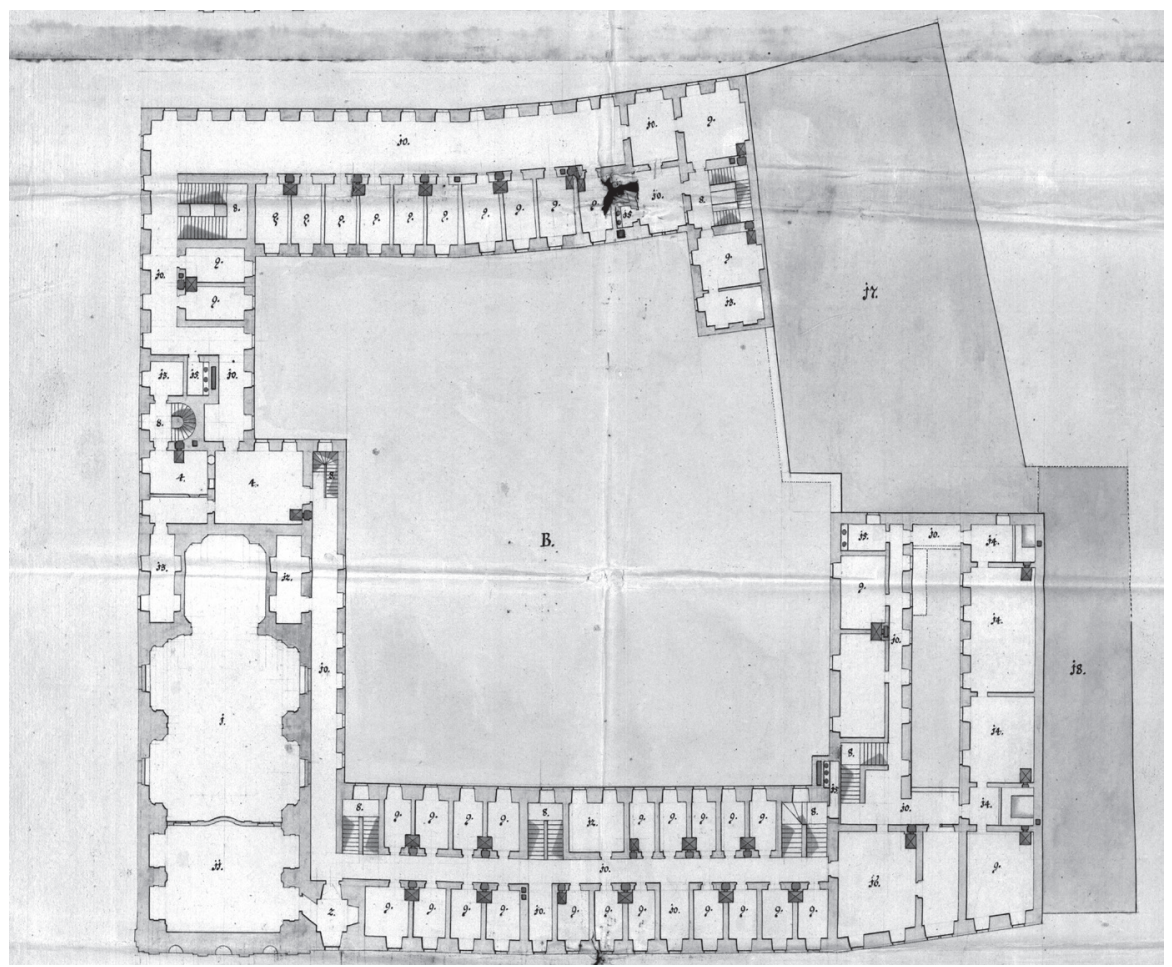

Fig. 3. Ground plan of the convent of Buda. First floor.

beds, folding screens, tables, chairs and cabinets for storing clothes and other necessary items. ${ }^{95}$ A ground plan attached to the reports of 1770 presents the two sickrooms on the first floor of the building, between two smaller rooms that both could be used as a kitchen. ${ }^{9}$

In contrast with the report and ground plan, the inventory in the dissolution files informs about only one sickroom with nine beds that could be separated with three folding screens ${ }^{97}$ that had to satisfy the needs of 53 inhabitants..$^{98}$

95 "Az beteg hazban vagyon két szoba egy konyha és a mellett egy ambitus, a nagyobbik Szobában vagyon egy oltár, a melnél a betegek[ne]k Szent Mise Szolgáltatik, és mind a két szobában az szükséges ágyok vannak, és ahoz tartozandó /: vulgo Spanische Wanth :/ asztalok, székek, és olymariumocskák a mellekben az fehér ruha, és masféle eszköz tartatik az betegek szükségére." MNL OL C 39 Ladula D Fasciculcus 40, f. 342r.

96 MNL OL C 39 Ladula D Fasciculcus 40. Ercklärung des gegenwärtigen Plan des Closters deren W. W. E.E. Closter Frauen Ord. S. M. Clarae in Ofen, f. 346.

97 “Scenae Hispanicae antiquae /: Spanische Wande :/ 3. / Lecti Novem” MNL OL C 103 - Poor Clares' convents - Buda - Inventatio Regiae Comissionis Pretiosororum in V[enerabili] Conventu S[ancti-] Monialium Budensium Ordinis S[anctae] Clarae repertorum et quidem ex Dono S[anctae] Elisabeth Reginae V[enerabilis] Conventus Fundatricis, f. 203r-v (Box 31).

$9^{8} \quad$ The community consisted of 37 nuns (Professin and Chorschwester), ten lay sisters and six novices. MNL OL C 103 - Poor Clares convents - Buda - Consignation deren in dem abolirten Offner Clarisser 


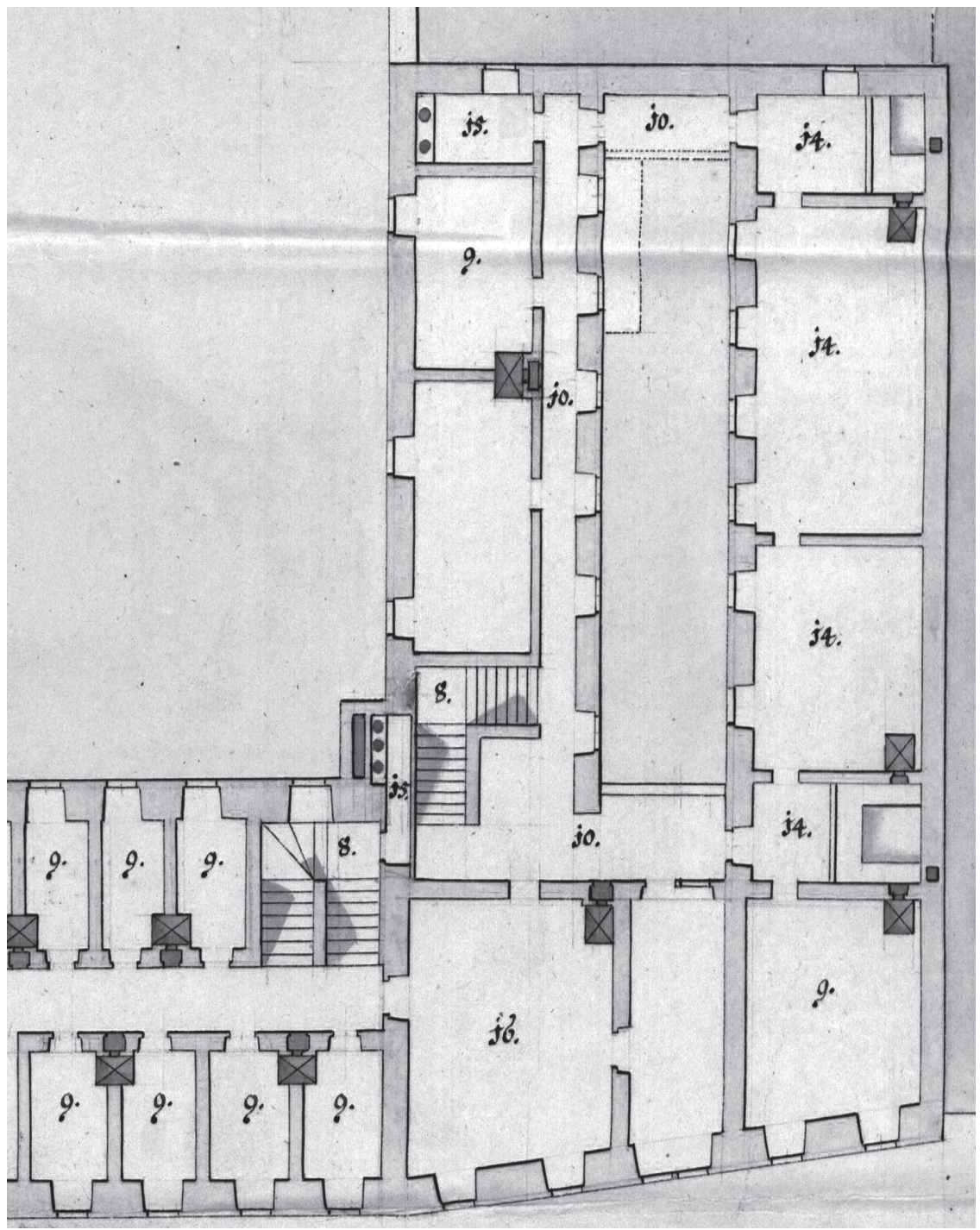

Fig. 4. The rooms of the infirmary marked with the number 14.

The room united the functions of a sickroom and a chapel, as it was equipped with everything necessary for nursing and for celebrating the Eucharist. There was a main

Closter sub Dato $10^{\text {ten }}$ April 1782 vorgefundenen Geistlichen Ordens Gliedern, ihrer Geistl[ichen] und Weltlichen Namen, item aufgehabten Dignitaet, Lebens Alter, verwendeten Jahren im Closter, und Erklärungen, zu welcher Lebens Art sich ein jegliches dieser aufgehobenen Closter Individuen künftighin entschlüssen wollen? Mit denen original Beylagen a $\mathrm{N}^{\text {ro }} 1^{\text {mo }}$ bis $53^{\text {tium }}$, ff. 1-12, f. 3, 13. (Box 31) Cf. MFKL Kézirattár, Jakosics Gyüjtemény 1. kötet, p. 131. 
altar decorated with an effigy representing the death of Saint Joseph and with a tabernacle. It was completed with two further side-altars ornamented with 16 glass-covered paintings. ${ }^{99}$ The rest of the liturgical equipment consisted of a glass-covered wax statue of the infant Jesus, an effigy of the Holy Trinity held forth by four nuns, a paten for the communion wafer, two cruets for oil and water, four candelabras, an alb, a rochet, a cord, a wooden crucifix, and five prayer stools of the sick. The walls were decorated with four old paintings and several smaller pictures. ${ }^{100}$ Further pieces of furniture provide insight into the daily life of the infirmary. A long table covered with green textile, six smaller tables covered with oilcloth, fourteen chairs, and a pewter lavabo hint that the sick members of the community consumed their meals in the infirmary. ${ }^{101}$ There were two small footstools and a lamp that served as a night light. ${ }^{102} \mathrm{~A}$ wooden cabinet was used to store white, worthless clothes for the sick - as it has been mention in the report in 1770. ${ }^{103}$ Two cabinets contained medicaments, that were probably acquired from local apothecaries, since the records do not provide evidence for their production inside the monastery.

The kitchen of the infirmary was not described either in 1770 or 1782 . Although it is mentioned in the inventory made in $1782^{104}$, its equipment was not listed and it cannot be revealed whether it was used to satisfy the special dietary needs of the sick ${ }^{105}$, served as a washing room or as a site - similarly to the case of Trnava - where medicaments could be prepared.

99 "Una Ara cum effigie Moriensis S[ancti] Josephi cum Tabernaculo ligneo, et aliis Aris duabus pictis, 16. vero sub vitro existentibus Imaginibus." MNL OL C 103 - Poor Clares' conventss - Buda - Inventatio..., f. 203r (Box 31).

100 "Item duo Candelabra Argentea Minoris Qualitatis / Duo ex Metallo flavo Candelabra, una patenula Argentea, cum duabus Ampullis aeq[uis] Argenteis ad Missae Sacrificium in hac Domo Infirmorum Diebus Dominicis celebrari solitum, Necessaria. / Una Alba. / Unum Superpelliceum. / Cingulus Unus. / Crucifixus Major ex Ligno Sculptus 1. / Effigies S[anctis]s[imae] Trinitatis ab infra 4 Moniali$\mathrm{u}[\mathrm{m}]$ Virgines exhibens. / Imagines pictae antiquiores in Pariete pendentes 4. / Theses in ordinariis Ligneis Ramis consistentes 20. / Scabella pro Oratione infirmorum deservientia 5. /.../ Diversae Imagines Papiraceae 24." MNL OL C 103 - Poor Clares' convents - Buda - Inventatio..., f. 203r-v (Box 31).

101 "Mensa longior Viridi Tela Tecta, et instructa 1. /.../ Mensulae parvae tela cerata obducta 6. / Sedes ordinariae Corio obducta 14. / Lavatorium ex Stanno 1." MNL OL C 103 - Poor Clares' monateries Buda - Inventatio... f. 203r (Box 31).

102 "Lampas Laminea pro Conservando Lumine Tempore Nocturno pro Infirmis 1. /.../ Scabella minora Lignea 2." MNL OL C 103 - Poor Clares' convents - Buda - Inventatio..., f. 203r (Box 31).

${ }_{103}$ "Unum Armarium ex molli ligno, in quo diversa pro Infirmis destinata, alba nullius pretij vestimenta continen[tur] / Duo Armaria ordinaria pro Conservatione Medicamentoru[m]" MNL OL C 103 - Poor Clares' convents - Buda - Inventatio, f. 203r (Box 31).

104 „In Cubili ad Culina[m] Infirmariae” MNL OL C 103 - Poor Clares' convents - Buda - Inventatio..., f. $208 \mathrm{r}($ Box 31).

105 About the role of the infirmary kitchens to provide meals to the sick differring from the usual diet of the community see: Krisztina OROSZ, Várak és kolostorok konyhái a középkori Magyarországon [Kitchens of Castles and Monasteries in Medieval Hungary], in: Elek Benkő - Gyöngyi Kovács (eds.), A középkor és a kora újkor régészete Magyarországon I-II. [Archeology of the Middle Ages and the Early Modern Period in Hungary] Budapest 2010, pp. 562-596, 562-596. 


\section{Pest}

The infirmary of the monastery of Pest was a relatively small sickroom that served a community of 21 members. ${ }^{106}$ The very modest equipment consisted of one bigger and one smaller cabinet, a chair and three litters that could be separated with two screens. The smaller cabinet contained ascetical and prayer books. The walls were decorated with six paper images and five paintings among which one represented Saint John of Nepomuceno. ${ }^{107}$

The small sickroom does not necessarily indicate the lack of medical supply: the monastery availed itself most probably of the services of secular healers. Although no medical invoices were preserved in the dissolution files, the petition of the abbess presented in the introduction mirrors the nuns' demand for a full set of medical services covered by a physicist, a surgeon, and an apothecary. This demand indicates a pre-existing practice of hiring professionals for a fixed, annual salary, as the abbess referred to the "previously enjoyed remunerations" of a surgeon and a physician that were supposed to be covered by the Hungarian Chamber (Ungarische Kammer) in the transitory period. ${ }^{108}$ While the monastery could successfully ensure medical supply for its inhabitants and, simultaneously, set limits to the medical costs through contracting professionals, the loss of its financial basis, and then of the community itself, terminated these agreements and the nuns had to seek for help individually.

\section{Conclusions and further research directions}

Coping with illness implied a complex set of practices that appeared in different configurations in each monastery, even if the houses belonged to the same religious order and each convent had to deal more or less with the same set of demands from the perspective of medical provision. Consultations with a doctor, nursing and cure with the help of medicaments and treatments could become necessary in any of the communities and each convent established an infirmary for their sick inmates. Nevertheless, the size and functions of the infirmaries, their capacities to produce medicaments, the knowledge and experience of their personnel or their suitability for devotional practices could be significantly different.

106 MNL OL C 103 - Poor Clares' convents - Pest - Consignation deren in dem aufgehobenen Clarisser Kloster zu Pest sub dato $11^{\text {ten }}$ Aprilis 1782. vorgefundenen Geistlichen Ordens Gliedern, ihrer geist- und Weltlichen Namen, aufgehabten Dignität, Lebens-alter, verwendeten Jahren im Kloster, und Erklärungen, zu welch einer Lebensarth sich eine jegliche dieser abolirten Kloster Individuen künftighin entschließen wolle? ff. 81-85 (Box 31). Cf. MFKL Kézirattár, Jakosics Gyüjtemény 1. kötet pp. 13. Here 22 names are listed.

107 Pictae maioris quantitatis Imagines sunt 5 . una sub vitro S[ancti] Joannis Nepomuceni. Imagines Papiraceae Sex Lecticae 3. Armarium maius 1. minus 1. Duo Spanische Wand dicta In praeattacto minori Armario continentur diversi libelli ascetici et precatorii, in materia cruda ut plurimum defectuosi / Una Sella corio obducta" MNL OL C 103 - Poor Clares' convents - Pest - Inventarium Universorum in abolito Conventu Monialium Clarissarum Pesthensium et Ecclesia earundem, repertorum, f. 358r (Box 31).

108 MNL OL C 103 - Poor Clare convents - Pest - Unterthänigste Bittschrift..., f. 376r (Box 31). 
The convents of Bratislava, Trnava and Buda provide examples of the interconnectedness of spiritual and medical care having its roots in medieval monastic medicine. Although the sickrooms could be turned into spiritual spaces by the sick inmates and other members of the community in any of the Poor Clares' houses, the infirmary chapels in Bratislava and Trnava and the liturgical equipment in the bigger, hall-like sickroom in Buda enabled participation in the holy masses and divine offices even in a weak condition. Besides the traditions and spiritual necessities, a practical aspect has to be also considered: the celebration of the Eucharist in the infirmary required a certain number of potential participants. The infirmaries of the aforementioned three bigger monasteries had 9-12 beds ${ }^{109}$, while the smaller ones in Pest and Zagreb only 3-4.

The medical demands could be satisfied both with the means of self-supply and with the services of external practitioners, however the shifts of emphasis between the two could be traced mainly from the perspective of the inner resources, as the external practitioners' invoices were preserved only accidentally.

The traces of medical self-supply refer most often to the making of medicaments. The usage of herbs and the preparation of spirits, plasters, and various extracts can be evinced in Bratislava and Trnava. The medicaments inventoried in the infirmary in Buda were not necessarily the products of the monastery, but their availability indicates that the nuns took care of stocking and having them at hand. Since all the investigated nunneries were founded in free royal cities, i.e. in medically well-supplied urban settings. Consequently, their motivation to invest in the production of medicaments cannot be explained merely with the lack of other alternatives. However, the invoices of apothecaries make it clear that the cost of medicaments made up a great part of everyday expenses and a domestic pharmacy could reduce the costs. Another way for the convents to ensure high-quality medical provision and simultaneously to lower its expenses was the practice of making an annual contract with surgeons and physicians as a collective and availing themselves of their services for a fixed sum that could reduce both the financial and the "organizational" costs of medical provision. The convent of Buda made a step even further as it accepted novices who had could cover the tasks of surgeons, too.

The quality and complexity of the provision provided by the Poor Clares for the sick or aging members of their order constituted an inherent part not only of the everyday life of the convent, but also of the nuns' visions of the future: by taking their wows, they also became part of a community that undertook their medical care for a lifetime. When Joseph II dissolved their convents, the state offered the option of joining another female convent providing health care or education. Some studies have already addressed the question how successfully the new members could be integrated into the life of the spared convents. ${ }^{110}$ The identification of the members of the dissolved

${ }_{109}$ There is not source that would inform about the exact number of beds in Bratislava, but considering the number of the nuns and the spatial arrangement of the infirmary, it is very likely that its capacities were more or less the same as of the convents of Trnava and Buda.

110 Christine SCHNEIDER, Die Auswirkungen der josephinischen Klosteraufhebungen auf den Wiener Ursulinenkonvent, in: Veronika Čapská et al. (ed.), Between revival and uncertainty: monastic and secular female communities in Central Europe in the long eighteenth century = Zwischen Aufbruch und Un- 
convents who had experience in nursing and skills for making medicaments or carrying out phlebotomy enables further inquiries. Had these nuns any motivation to pursue their careers in health care? Could they be directed into the institutions of public health care? Did their skills facilitate their integration into other convents? Could they make use of their knowledge in the secular world?

Gaining insight into the medical care provided by the convent can also shed light on motives in the agency of the nuns that has not been considered. The provision the nuns received in their convents could influence their expectations regarding medical care. The willingness of the nuns to accept the option of joining another convent after the dissolution - and to contribute to the public good with their activity - could also depend on their demand for a community that could undertake their medical provision. The question whether such expectations could motivate the nuns to comply with the state agenda, or they rather made them create new spaces and networks for and by themselves according to their personal, devotional and corporeal agendas can be hardly answered with a simple yes or no. Nevertheless, bearing in mind this question can still enable future researchers to read the sources informing about the post-abolition plans and careers of ex-nuns both with and against the grain.

gewissheit: klösterliche und weltliche Frauengemeinschaften in Zentraleuropa im "langen" 18. Jahrhundert Opava 2012, pp. 131-154; Gertraud RAZESBERGER, Die Aufhebung der Wiener Frauenklöster unter Joseph II in den Jahren 1782 und 1783, Wien 1964. 